\section{Journal of Engineering}

journal homepage: www.joe.uobaghdad.edu.iq

Number 12 Volume 24 December 2018

أوجه التقارب والإختلاف بين العمارة المستدامة والعمارة الخضراء (دراسة مقارنة)

\author{
أ م د إنعام البزاز \\ قسم هندسة العمارة / رئيس القسم \\ كلية الهندسة

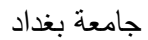

\author{
د. رائد عبد الجبار الطالبي \\ باحث / مهندس معماري إستشاري \\ كلية الهندسة - قسم هندسة العمارة \\ جامعة بغداد
}

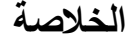

يقوم البحث بدراســة خصــائص العمارة المســتـامة "Sustainable Architecture" ، والعمارة الخضــراء areen" كمنهجية عمومية للبحث ضــــ Architecture"

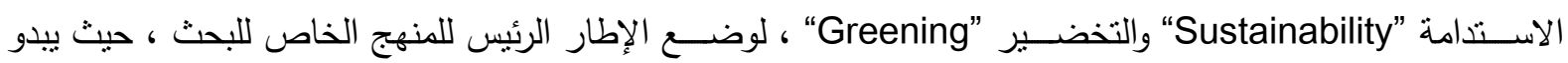

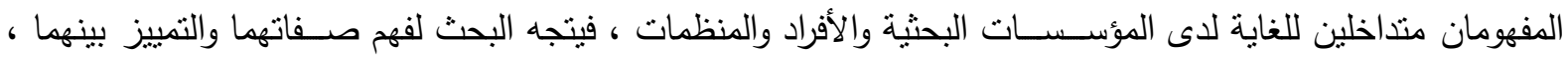

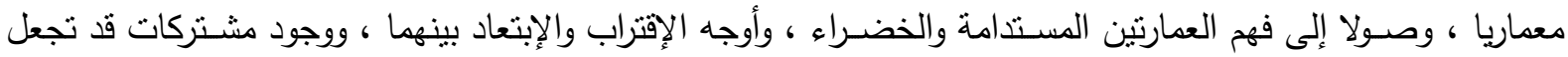

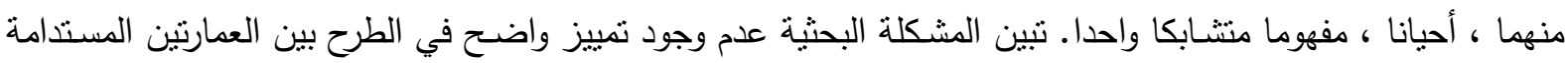

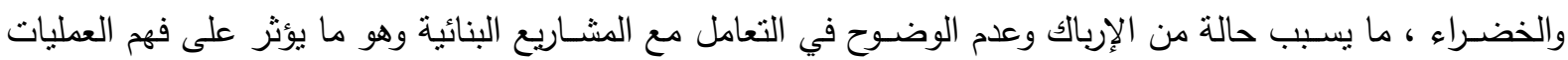

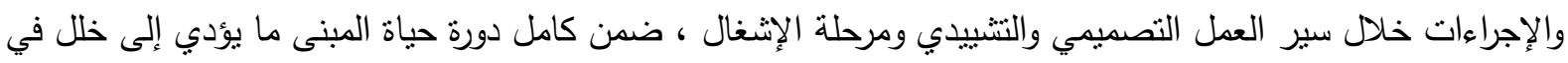
فهم بنية تصاميم الأبنية فضلا عن التتفيذ والتشغيل. يفترض البحث وجود ألية مكونة من مؤشرات بيئية ومعمارية ، مهوتها التفريق بين مفهومي العمارة المستدامة والعمارة الخضراء وتعتمد هذه الآلية على عدة عناصر تشكل بمجموعها أداة اختبار

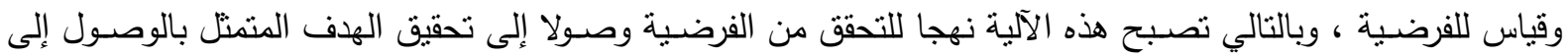

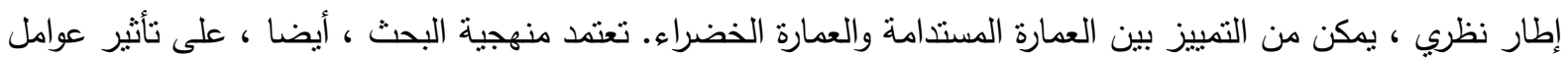

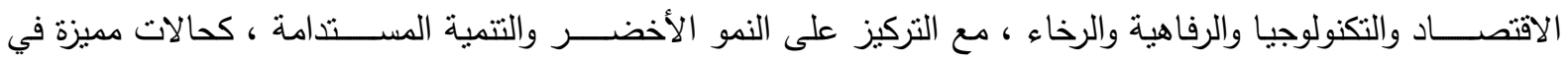

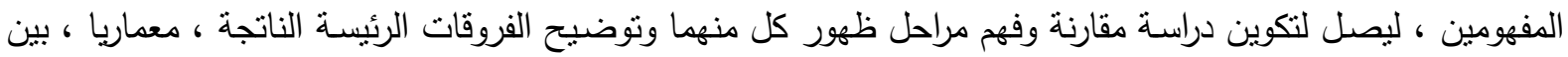

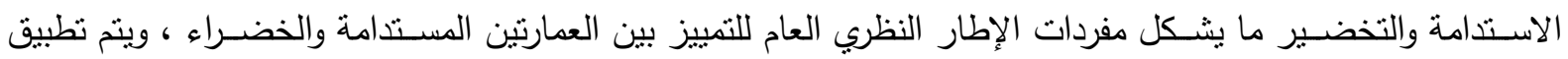
الإطار النظري على مشروعين معماريين صديقين للبيئة ، والبحث في خصائصهما البيئية والمعمارية لتحديد تواجد مفردات ومواصفات المبنى المستدام والمبنى الأخضر في كل منهما.

*Corresponding author

Peer review under the responsibility of University of Baghdad.

https://doi.org/10.31026/j.eng.2018.12.10

2520-3339 (C) 2018 University of Baghdad. Production and hosting by Journal of Engineering.

This is an open access article under the CC BY-NC license http://creativecommons.org/licenses/by-cc-nc/4.0/). Article received: $17 / 12 / 2017$

Article accepted: 13/11/2018 


\title{
Similarity and Difference between Sustainable and Green Architecture (a Comparative Study)
}

\author{
Dr. Raed AbdulJabbar AlTalebi \\ Researcher / Consultant Architect \\ Dept. of Architecture - College of Engineering \\ University of Baghdad \\ raed.altalebi@gmail.com
}

\author{
Assistant Professor Dr. Inaam Al-Bazzaz \\ Dept. of Architecture, Head \\ College of Engineering/University of Baghdad \\ inaam.bazzaz@yahoo.com
}

\begin{abstract}
The research is concerned with studying the characteristics of Sustainable Architecture and Green Architecture, as a general research methodology related to the specific field of architecture, based on the differentiation between two generic concepts, Sustainability and Greening, to form the framework of the research specific methodology, where both concepts seem to be extremely overlapping for research centers, individuals, and relevant organizations. In this regard, the research tend towards searching their characteristics and to clearly differentiates between the two terms, particularly in architecture, where the research seeks understanding sustainable and green architectures, how they are so close or so far, and the possibility of finding common features between them that might make them as a one synaptic concept. The research problem focuses on that there is no clear differentiation between sustainable and green architectures, what causes a matter of confusion and unclarity in dealing with building projects what affects understanding processes and procedures during the progress of design, construction, and operation, within the whole building life cycle, and this leads to a defect in understanding the formation of building design, construction and operation. The research hypothesis shows that environmental and architectural indicators can form a mechanism to differentiate between sustainable architecture and green architecture. This mechanism depends on several elements that form, together, the hypothesis testing tool, and in turn, this tool will become a method to verify the hypothesis reaching accomplishing the goal of the research (formation of a theoretical framework) that enable to differentiate between sustainable and green architectures. The research methodology depends, also, on the effects of factors like economy, technology, welfare, and else, with focusing on the green growth and sustainable development as distinguished statuses in the two concepts, to reach establishing a comparative study and understanding their developing stages and clarifying the main differences between sustainability and greening, architecture wise, to form the elements of the theoretical framework to differentiate between sustainable architecture and green architecture. The theoretical framework is applied in two environmentally friendly architectural projects (case studies) to search their environmental and architectural features to reveal the availability of the features
\end{abstract}


and characteristics of a sustainable building and a green building in each one of them.

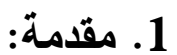

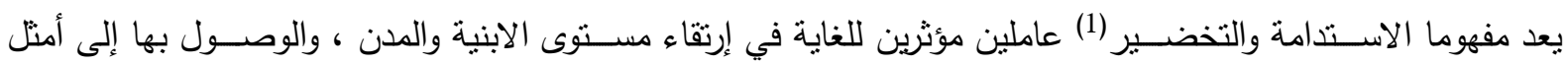

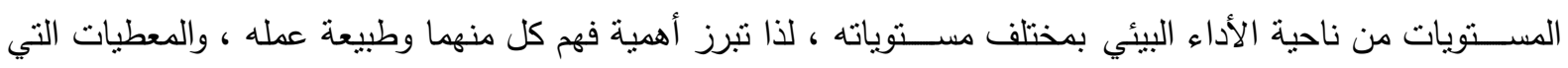

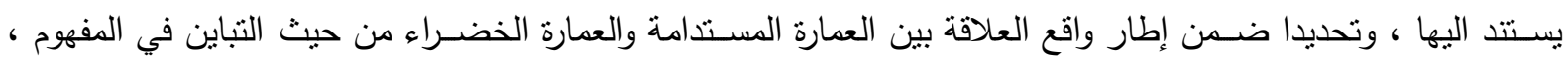

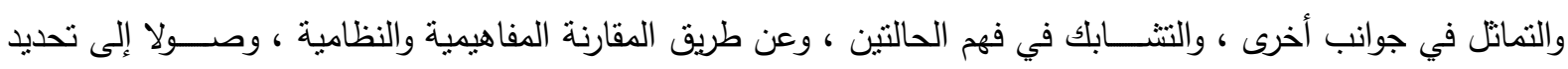

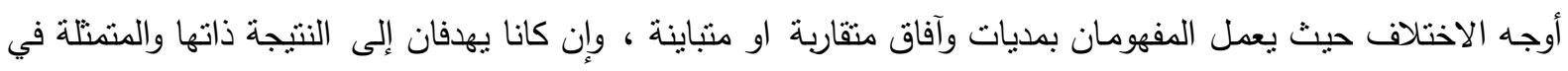

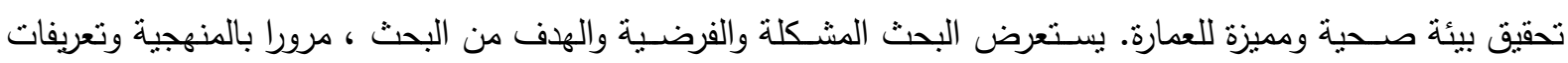

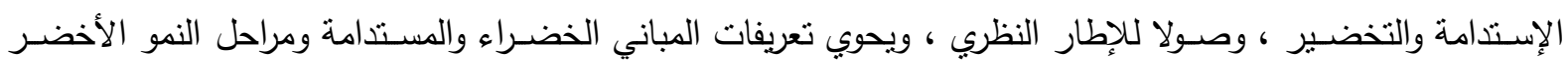

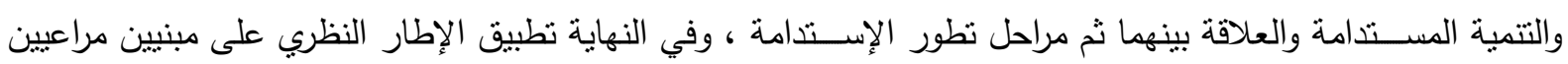

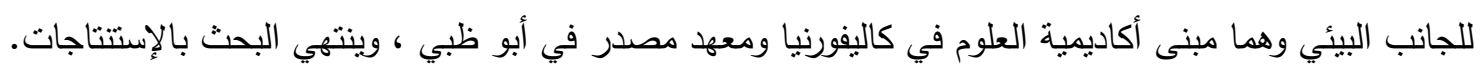

\subsection{1 ألمشكلة والفرضية والهذف:}

ييرز التداخل في الطرح بين العمارة المستامة والعمارة الخضراء من حيث وجود نوع من اللبس في الاستخدام والتطبيق ،

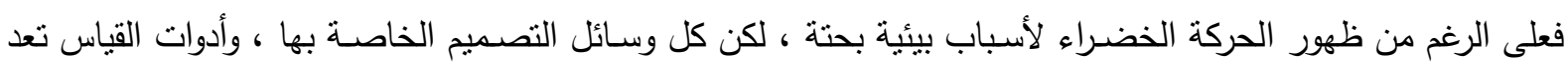

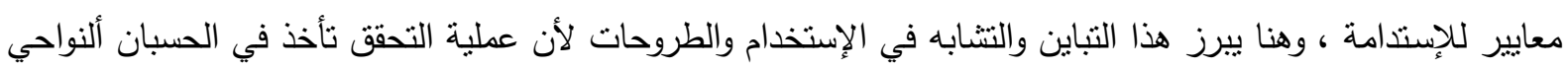

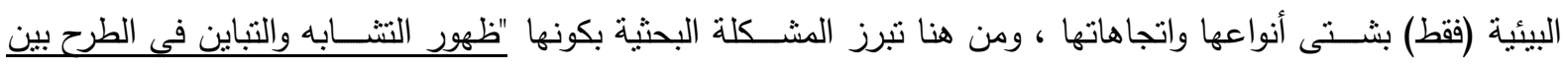

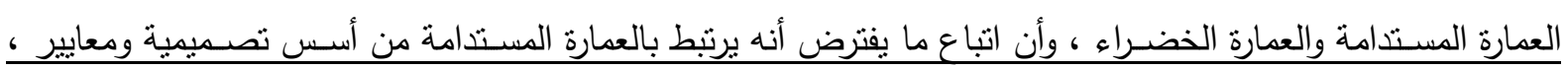
يرتبط وبصورة مشوشة فى حقائق العمارة الخضراء".

يوضح البحث ان الثباين الموجود بين المفهومين ، يؤدي إلى حدوث خلل في فهم البنية الخاصة بالعمل التصميمي للأبنية

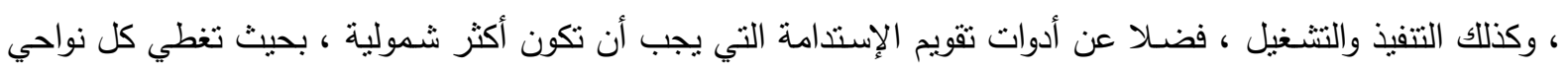

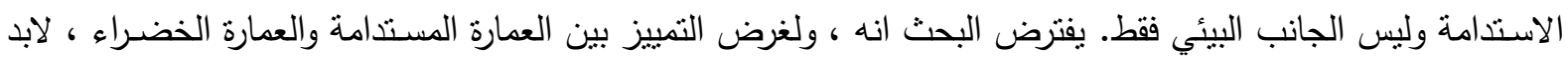

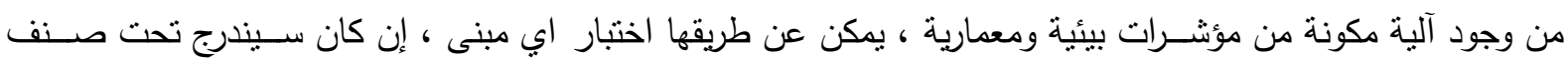

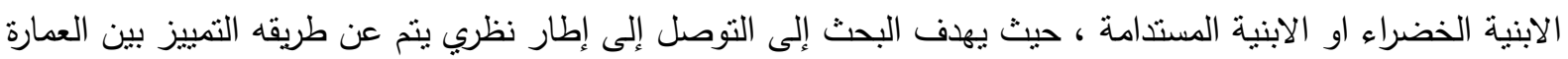
المستدامة والخضراء ضمن إطار دراسة مقارنة تعتمد التسلسل في الطرح والمقاربة الدفاهيمية والنطبيقية. 
يعتمد البحث في طرحه للموضوع على تحديد كل المقومات والمعطيات العامة والتخصصية لمفهومي الاستدامة والتخضير بوضوح وبشكل عام ، ضمن الإطار الفردي والثـامل ، وذلك ضمن الواقع الخاص بالعمارة على وجه التحديد ، والتوصل إلى إطار نظري يمكن من اختبار الفرضـــية البحثية وبالتالي تحقيق الأهداف ، كما ينطرق البحث إلى الى المقارنة بين مثالين

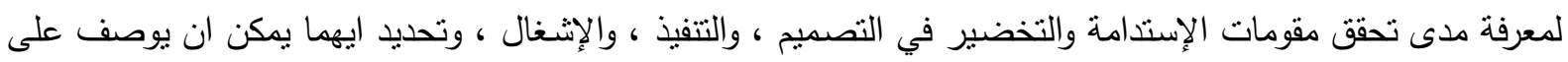

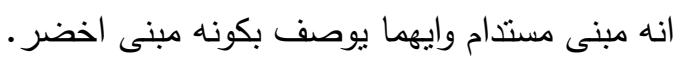
2. التعريفات - ألإستدامة والتخضير:

هناك تعريفات كثيرة للاستدامة ، بوصفها الفكرة الرئيسة فضلا عن تعريف التتمية المستدامة والتتمية الحضرية المستدامة، ويمكن بيان التعريف الأساسي لكلمة (Sustainable): (مستدام كصفة) - بأنها قدرة الثيء على على أن يتم استخدامه بدون أن يستتف أو يتلاشسى تماما ؛ ما يرتبط بالوسـائل والمناهج التي لا تعمل على استتفاد الموارد الطبيعية أو تلاشيها بصـورة

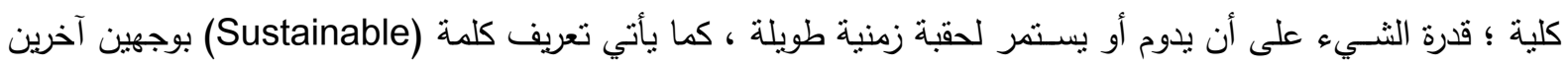
هما:

$$
\text { القدرة أن يكون الثيء مستداما. }
$$

(2) -أ: كونه طريقة لحصاد أو استخدام مورد ما ، بحيث أن هذا المورد لا ينضب أو لأ لأيتتفد أو لا يتضرر وقتنيا

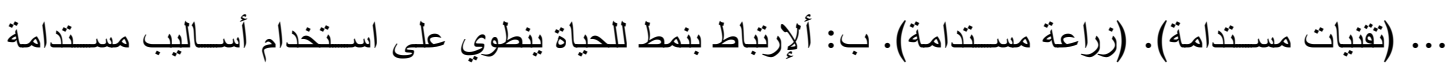

$$
\text { [Merriam-Webster Dictionary, 2014] - (مجتمع مستدام) }
$$

أما بالنسبة لكلمة (Green) الإنكليزية الني تعني (اللون الأخضر ) فقد جاء استخدام كلمة (أخضر /خضراء)/ (تخضير)

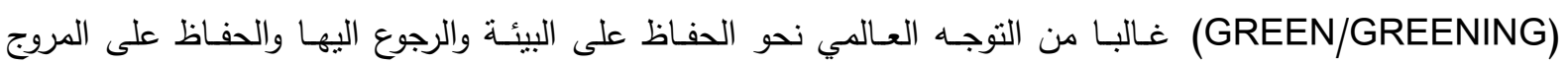

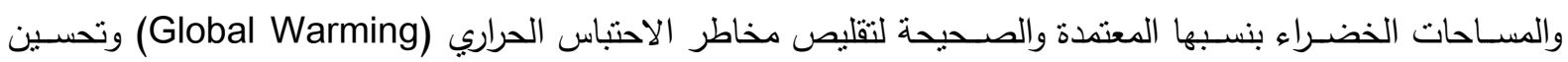
الأجواء ، أو تغطية السـقوف بالنباتات الخضــراء لنفس الغرض فضـــاء عن ما ســبيته زيادة نسـبة ثناني أوكسـبـ الكاربون المنبعث ، من مشـكلات في الجو والمناخ ، وكذلك ازدياد أسـعار الوقود في أوقات كثيرة ما دفع إلى إيجاد السـبل الكفيلة

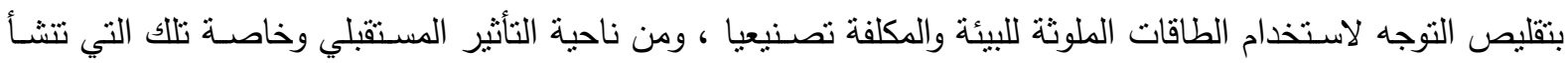

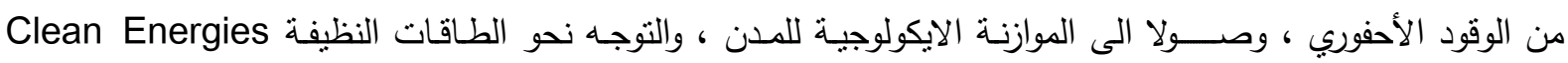
والمتجددة Renewable Energies ، حيث ظهرت بسبب ذلك حركة تطورت بموجبها الصـناعة الخاصسة بأنواع الطاقة الجديدة ، مثل استخدام الرياح (Wind Turbines) المنفعلة والفعالة ، وألواح الطاقة الثمسية (Solar Cells) واستخدام

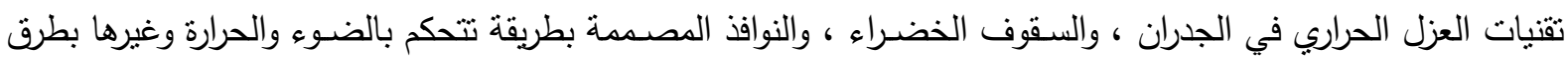
مؤتمتة ، وغيرها من التقنيات والصناعات.

\section{3. ألإطار النظري - مابين الإستدامة والتخضير:}

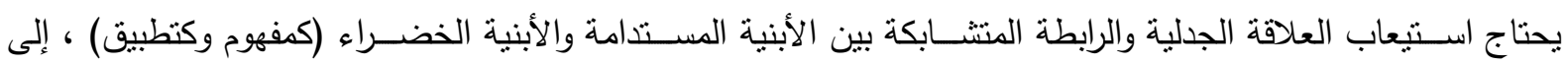
الدخول في الاسـتدامة والتخضـير بمختلف أبعادهما ونظمهما (حتى تلك المرتبطة بالنشـأة ، أو التي لا ربط مباثـر بينها وبين العمارة) وذلك بهدف إيجاد مقومات تلك الرابطة التي توصل إلى حل التشـابك في الفهم والارتباك الحاصل في ونس إدراك 


\section{Number 12 Volume 24 December 2018 Journal of Engineering}

معنى كل منهما ، والتداخل والفروقات والمشتركات بين الحالتين. يتحدث البحث في إطاره النظري العام والثشامل عن أنماط

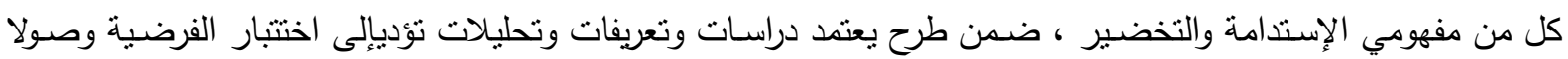
لالهدف والاستتناجات.

\section{3. مفاهيم المبنى الأخضر والمبنى المستثام:}

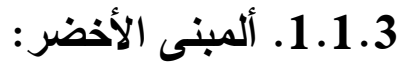

توجد دراسـات كثثرة نوضـح ماهية المبنى الأخضر أو كيف يمكن بالفعل أن يكون، تتراوح ما بين عد مبنى ما ليس "بسوء"

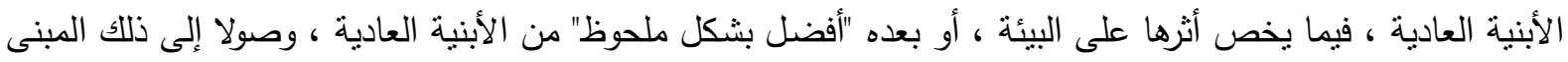

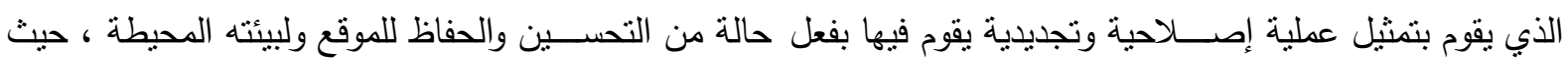

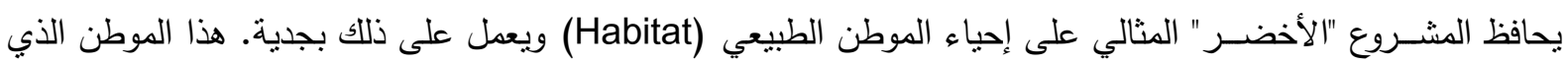

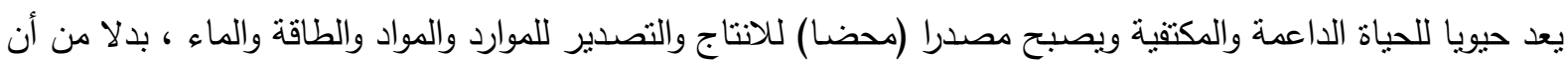
يكون مصدرا (محضا) للإستهلاك. هنا يمكن تعريف بناية خضراء معينة بأنها: "تتلك البناية التي تقوم طرق بنائها وتشييدها

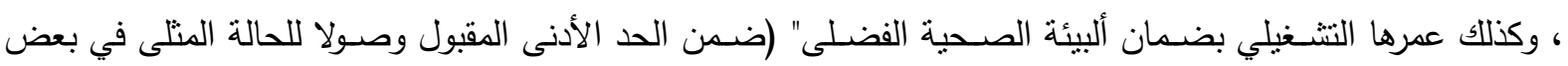

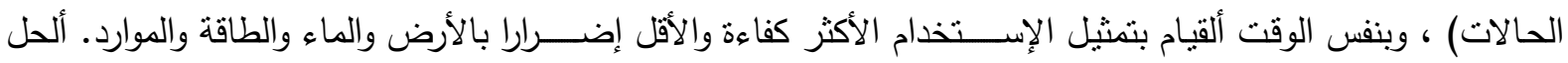

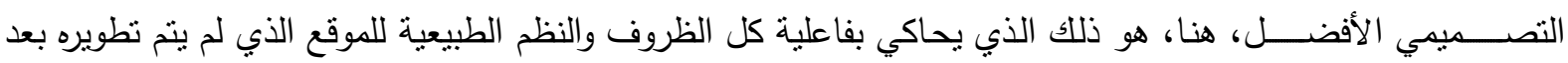

.[GGGC, 2014]

تعريف آخر للمبنى الأخضـر بكونه: (الممارسـة الخاصـة بإيجاد منشآت واستخدام عمليات مسؤولة بيئيا ، وتراعي الكفاءة بالموارد وذلك عن طريق دورة حياة المبنى ، إبتداءا من تحديد الموقع مرورا بالتصميم والتشييد والتشغيل والصيانة والتأهيل

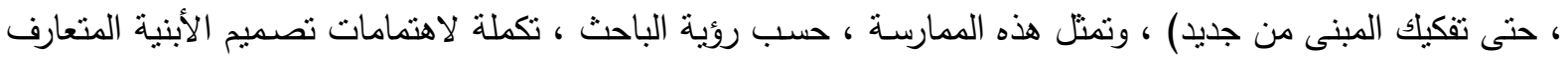

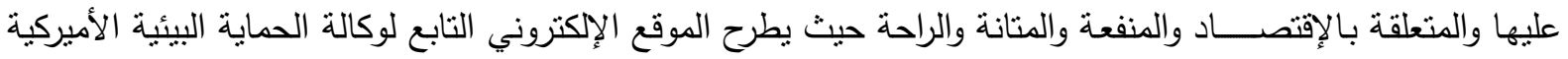
[archive.epa.gov] (US Environmental Protection Agency)

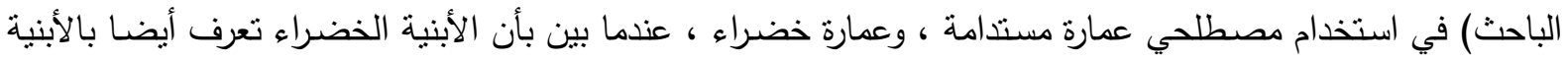

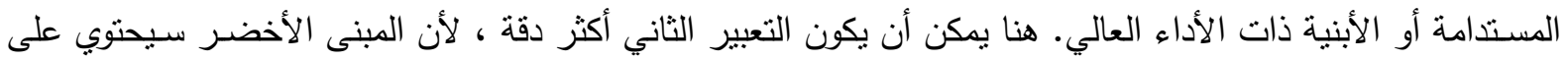

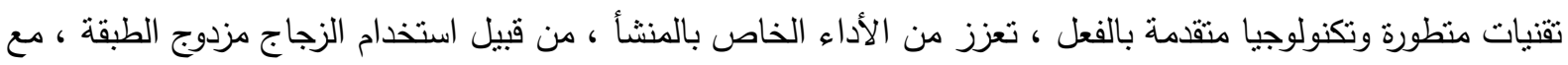

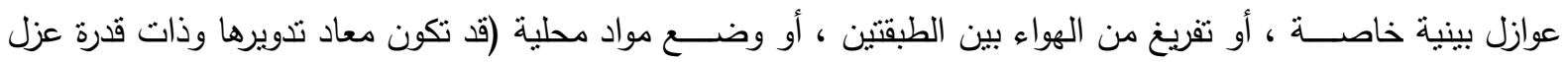

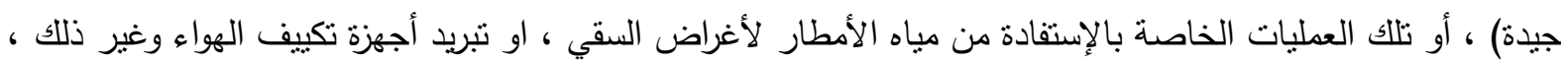
حيث أن كل هذا بحاجة إلى تقنيات عالية ويجب أن تكون منخفضة التكاليف (أو بتكلفة مبلئية عالية نسبيا Initial Cost)

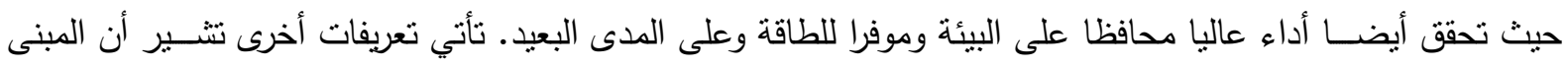

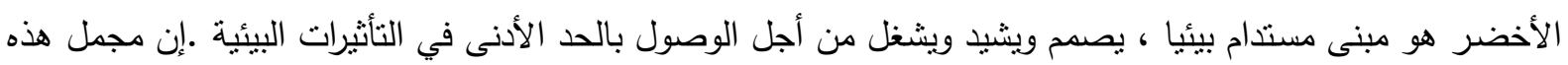

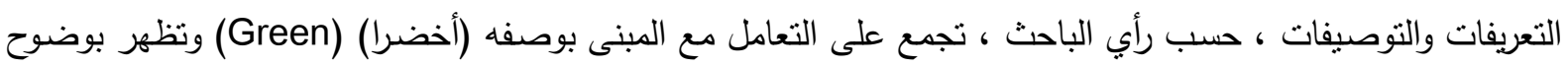

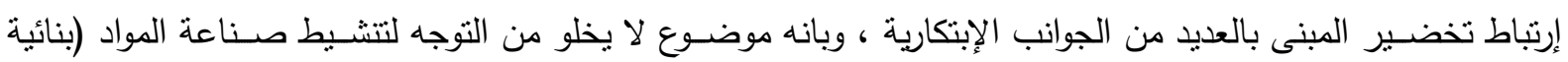

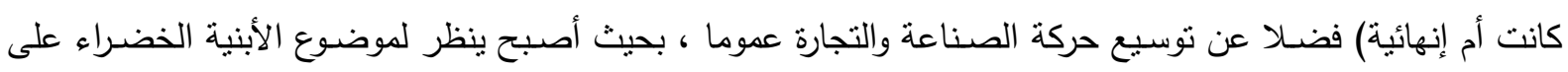

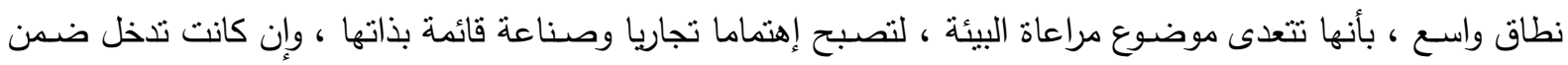


نطاق الصناعات ذات الأهداف السامية ، والتي ليس لها أضرار كبيرة بالضرورة ، إذ يتبين أن جانبي الإقتصاد المجتمعي

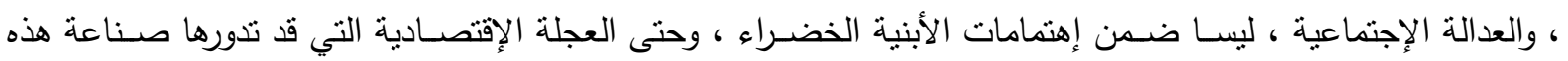

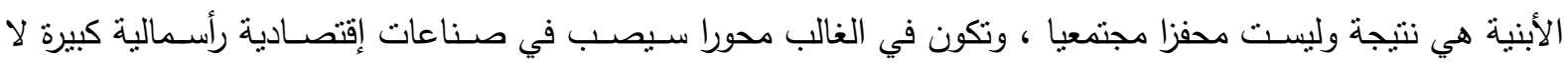
ترتبط إلا بشكل قليل بفائدة المجتمع وتتمية حياته ، وحسب روئية الباحث.

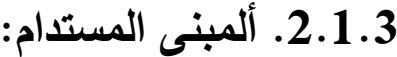

تبقى البيئة بوصفها هدفا سـاميا ، وصناعة متقدمة ومتطورة ، عمادا للعمارة الخضـراء ، وييقى السندان الرئيسان الآخران

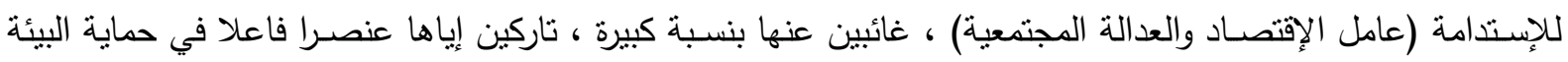

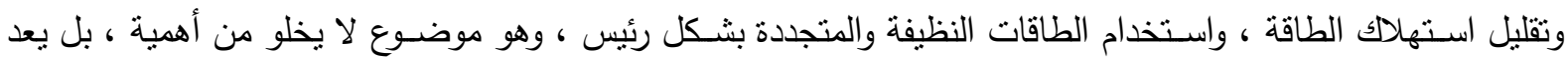

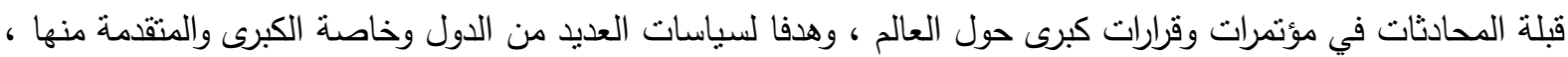

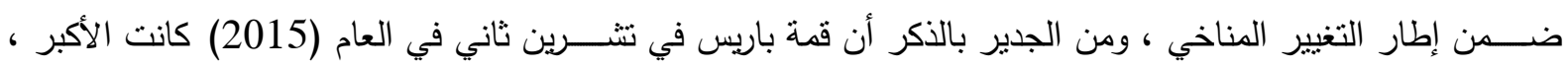
ووقعت على توصيات لحماية الأرض (وكانت في جوهرها قمة عن الإستدامة ، ضمت بين طياتها جانب الطاقات المتجددة

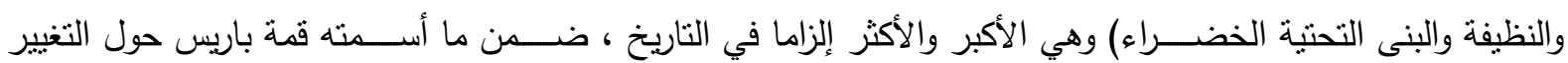

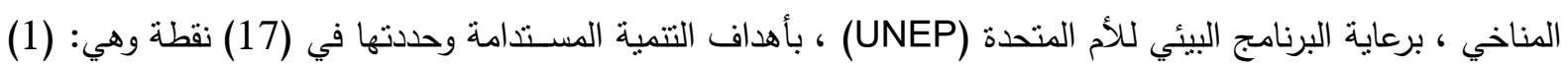

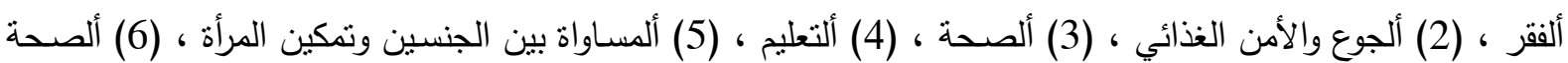

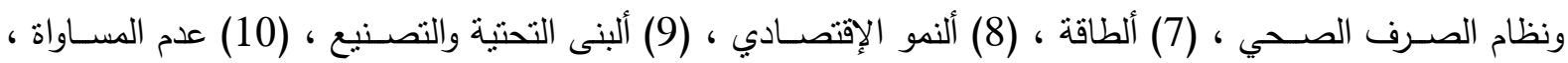

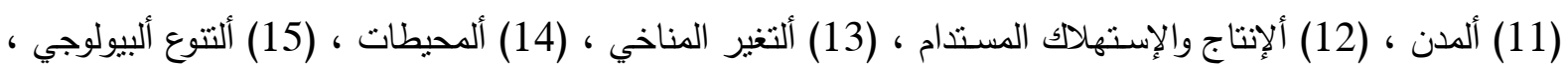

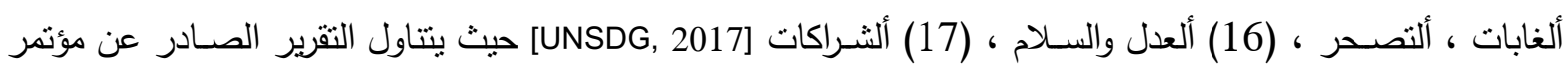
العمل الدولي (ألدورة 102 في العام 16 2013) ، والمنبثق عن مكتب العمل الدولي في جنيف (ســـويســرا) ، تحديين من

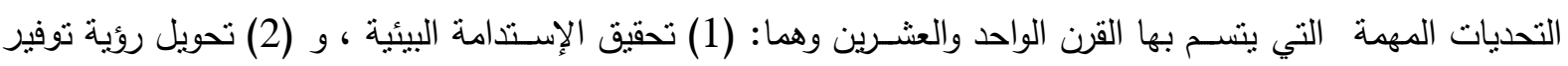
العمل اللائق للجميع إلى حقيقة واقعة ، وهنا يوضـح هذا التقرير وبدقة ، وضمن هذه العبارة: "بأن المؤتمر يركز على أحد التد جوانب الإستدامة وهي البيئة ، ويتضح هنا أن الإستدامة هي ليست التصميم الأخضر ، بل أن فيها عدة جوانب ، والتقرير يركز على إحداها" [ILO Report V: Sustainable Development, Decent Work and Green Jobs, 2013].

يمكن أن يكون لإنشاء الأبنية وتشـيلها ، تأثنرات مباشـرة أو غير مباشرة على البيئة ، وعلى المجتمع ، وعلى الإقتصـاد ،

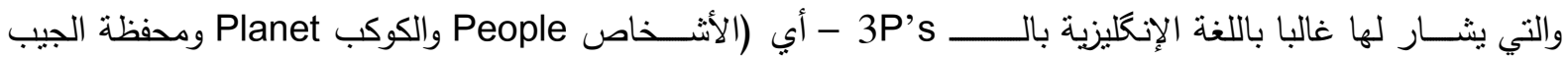

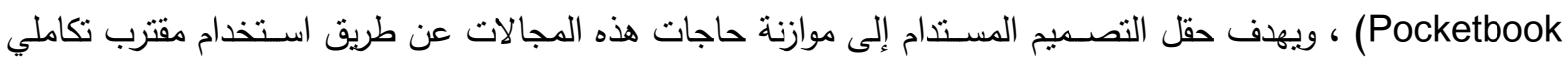
لانشاء حلول تصميمية تعود بالفائدة على كل المجالات الثلاث. يمكن بيان أن الهدف الرئيس من التصميم المستدام هو :

1- التقليل من ، أو حتى التجنب التام لنضــوب ونفاد الموارد الحرجة ، كالطاقة والمياه والأراضــي والمواد الخام. 2- منع التدهور البيئي الذي تنبيه المنشآت والابنية والبنى التحتية خلال مراحل دورة حياتها. 3- إيجاد بيئات مبنية يمكن أن تعد إنتاجية وأمنة ومريحة وقابلة للعيش. 
تمتاز الأبنية بأنها تنــتخدم الموارد (ألطاقة والمياه والمواد الخام وغيرها) ، كما تتتج وتولد النفايات والمخلفات (ألناتجة عن

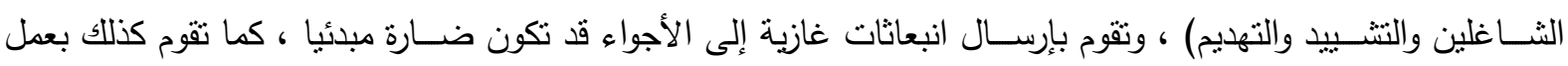

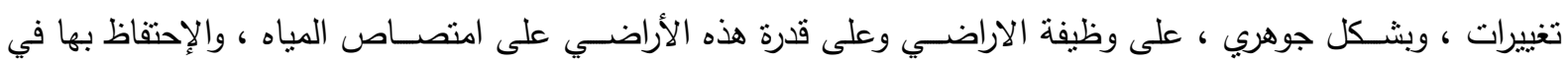

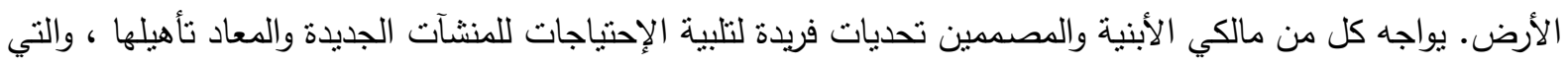
تكون ذات إنتاجية وصحية ومحمية وأمينة وسـهلة الوصول والاخول ، وفي نفس الوقت عليهم التقليل إلى الحد الأدنى من

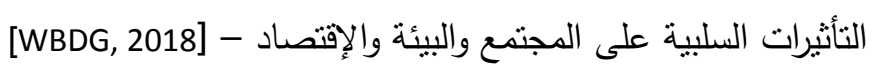

بينما تقوم موسـوعة (ويكيبيديا) بتعريف العمارة المسـتـامة (وليس الابنية): "بأنها العمارة التي تطمح إلى التقليل إلى الحد

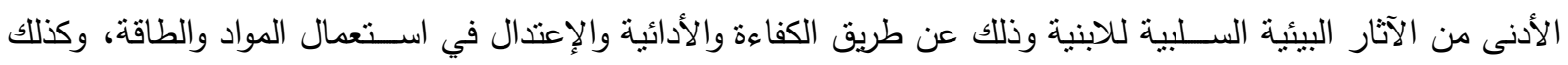

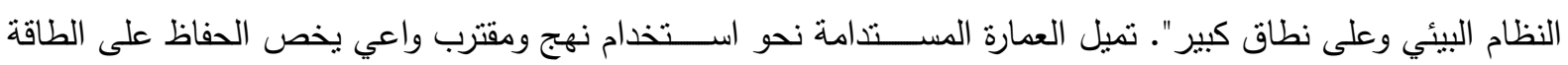

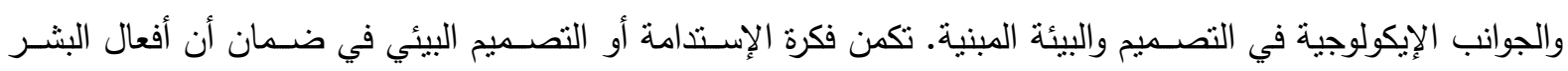
وقراراتهم الحالية لا تمنع فرص الأجيال المستقبلية ، وعلى الرغم من أن الإستدامة كمصطلح يعد أحد أكثر المفاهيم انتشارا

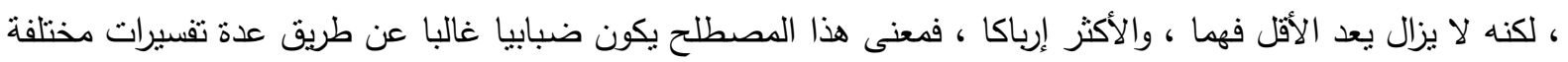

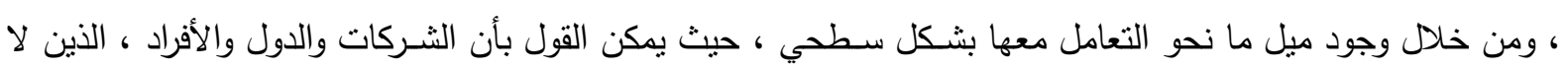

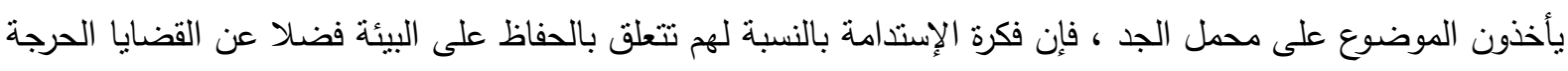

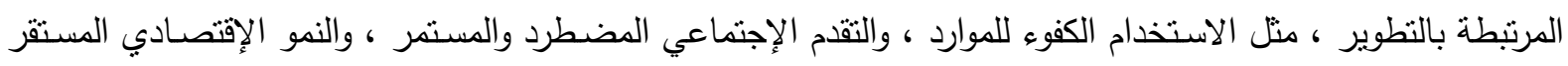

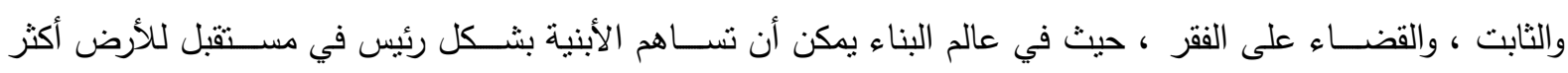

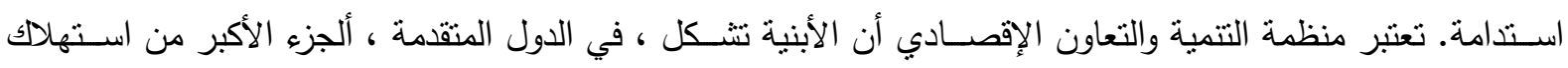

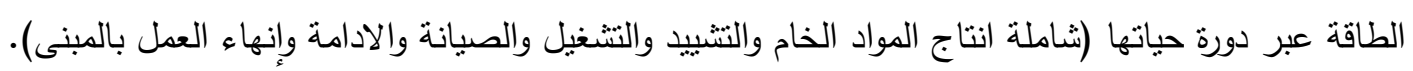

\section{3. مراحل ألتطور البئي بين التنمبة المستدامة والنمو الأخضر:}

يعد تفحص التطور التاريخي للعلاقة بين الكائنات البشـرية والبيئة الفيزيائية ، خطوة مهمة في سـبيل فهم بزوغ مفهومي أو مصطلحي "ألتنمية المستدامة" و"النمو الأخضر" حيث نم تقسيم النطور إلى ثلاث حقب بيئية بارزة وهي:

1 . ألحقبة البيئة الأولى: تجاهل مطلق (أو يكاد يكون مطلقا) للبيئة:

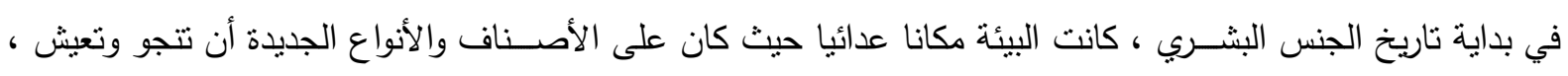

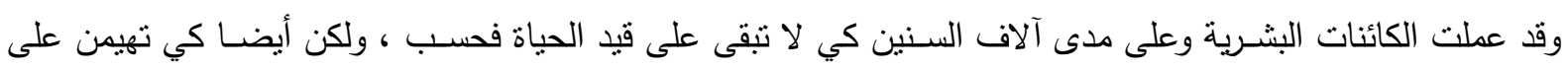

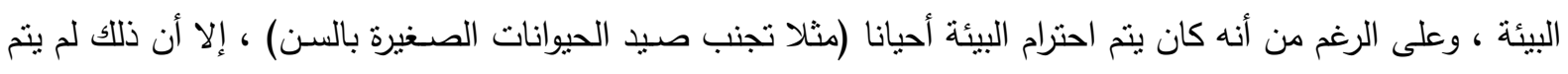

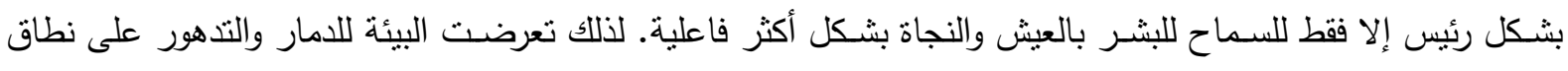

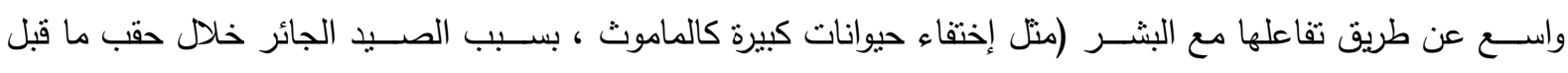
التاريخ) [GGGC, 2014]

\section{2. ألحقبة البيئية الثانبة: معضلة الحمابية البيئية في مقابل النمو الإقتصادي:}

خلال القرون المتأخرة وتحديدا مع ذروة الوصــول إلى الثورة الصــناعية على وجه الخصـوص ، قامت المجتمعات الغربية بالتحرك نحو ما يسـمى بالحقبة البيئية الثانية ، وخلال هذه الحقبة ، بدأ الناس يفهمون - ولو ببطء فئ في البداية ولكن لاحقا 
بشكل اسرع قليلا - أن للنمو الإقتصادي في الغالب ناثيرا سلبيا على البيئة ، حيث ظهرت ألعديد من الضغوط الإجتماعية

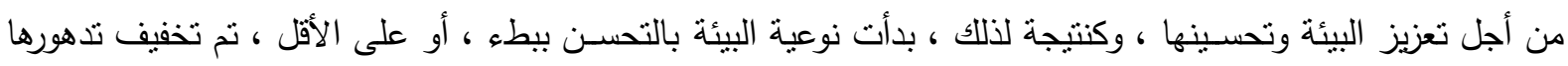
ببطء. لحماية البيئة كلفة تعمل حتما على إبطاء النمو الإقتصـادي ، في الإقتصـاد ، حيث تبدو المعضلة واضحة: حماية

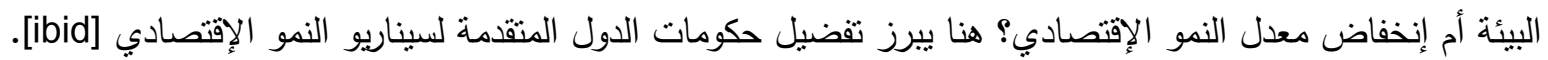

\section{3. ألحقبة البيئية الثالثة: ألتنمية المستدامة (Sustainable Development)؛}

أما خلال بداية عقد السبعينيات في القرن العشرين ، بدأت تظهر وتتطور الأسئلة المتعلقة بحدود النمو الإقتصادي وعواقبها

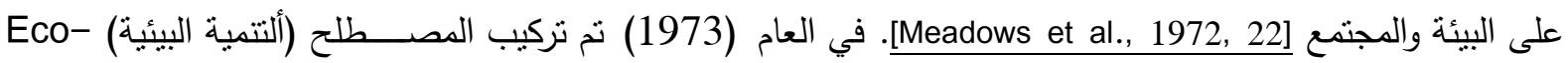
(United Nations Environmental UNEP وذلــك من قبـل البرنــامج البيئي للأمم المتحـدة development ويعرف بأنه "ألنتمية المحافظة والمقاومة للتغيير ، والمســنتدة على الإســـتخلال الأمثل طويل الأمد لموارد المحيط الحيوي" وبأنه "مقترب للتتمية عن طريق الإنــتخدام الرثـــيد للموارد الطبيعية بواســـة التكنولوجيا ونظام الإنتاج

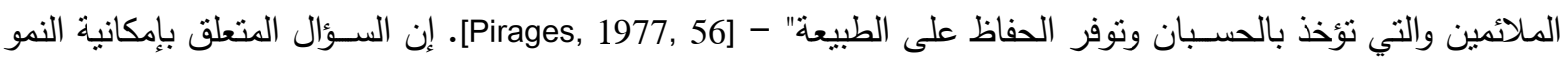
الإقتصـادي المسـتمر قد وجد إجابته في نهاية ســبعينيات القرن العشـرين ، حيث يمكن لنمو اقتصــادي معين أن يكون

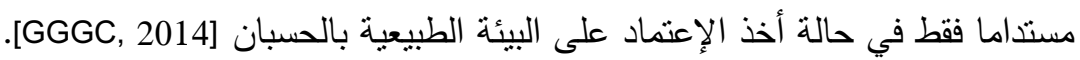
3.3. ألعلاقة بين التنمبة المستدامة والنمو الأخضر:

يبين (إيفتثميوس زيرفاس) EFTHIMIOS ZERVAS) بأن تطوير مفهوم أو فكرة "التتمية المسـتدامة، قد حصـل خلال

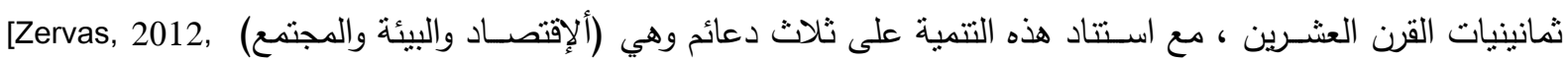

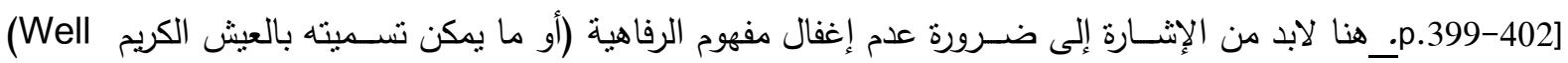

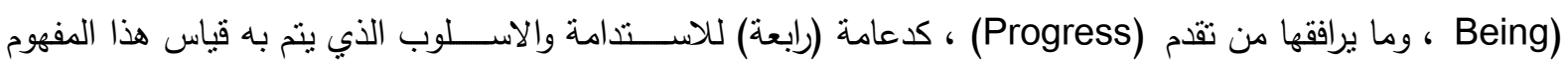

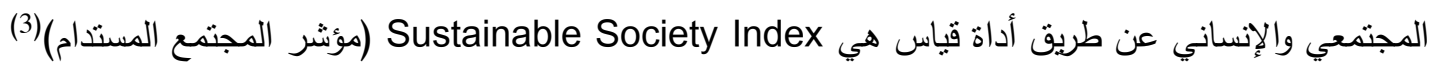
United Nations عرفت ألتتمية المستدامة لأول مرة خلال إجتماعات اللجنة العالمية للبيئة والتتمية ألتابعة للأمم المتحدة World Commission on Environment and Development (WCED) (والمعروفة أيضـا باسم لجنة برونتلاند) ، وجاء في تعريفها بأنها "تتمية تلبي حاجات الحاضر دون المسـاس بقرة الأجيال المسـتقلية على تلبية حاجاتها". يعد هذا التعريف نقطة تحول وشـروع لصـانعي السياسـات في الحكومات والعلماء ورجال

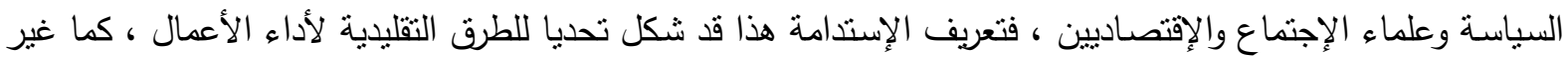

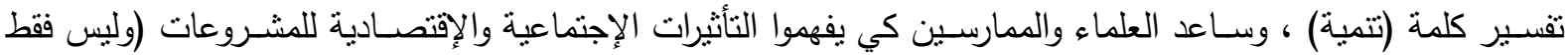
الآثار البيئية) كون ألجنس البشري يتفاعل مع محيطه. يحتوي هذا التقرير أيضا على فكرتين رئيستين وهما:

$$
\text { فكرة "الحاجات" ، وخاصة حاجات فقراء العالم ألني يجب ان تعطى لها الأولوية القصوى. }
$$

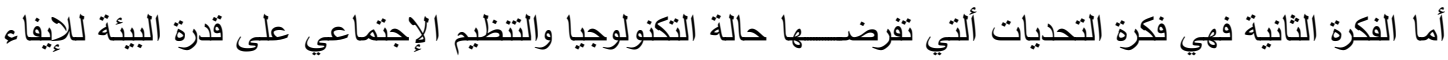

بالحاجات الحاضرة والمستقبلية. [Poveda \& Lipsett, 2011, 36].

(2) إيفثيميوس زيرفاس ، يوناني ، دكتوراه في الكيمياء ، أستاذ مشارك في مدرسة العلوم والتكنولوجيا - ألجامعة اليونانية المفتوحة. Sustainable Society Index (3) (SSI)

العالم (Saisana \& Philippas, 2012, 3 (S) 
بينما تعد فكرة "النمو الأخضـر" "Green Growth" أكثز حداثة ، فإن للمفهومين ألكثير من الإختلافات. يكمن الإختلاف

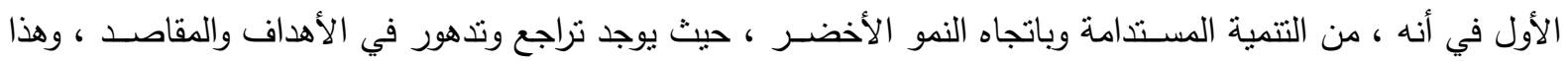

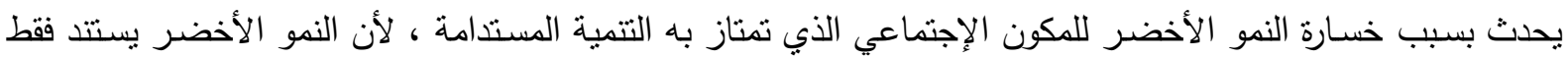
على البيئة والإقتصـاد. أما الإختلاف الثاني فهو أن النمو الأخضـر يتعلق ويرتبط بالنمو (Growth) فقط وليس بالتتمية الإنية

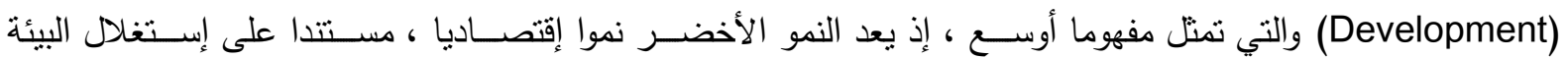

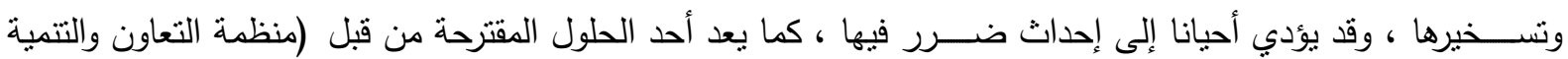

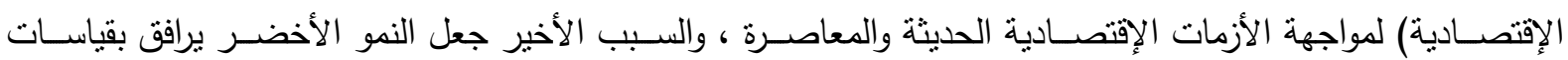
اقتصــادية واجتماعية كالتدهور في التعليم النظامي ، وصـولا إلى مجرد اكتسـاب المهارات ، فضــلا عن الزيادة في الدعم

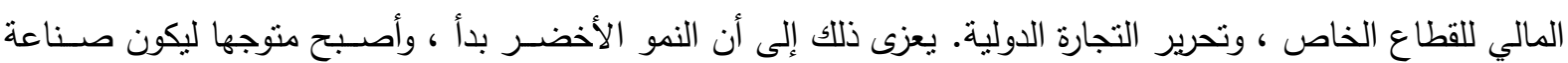

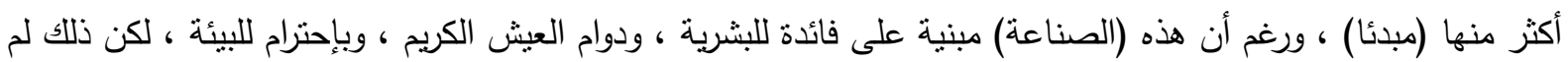

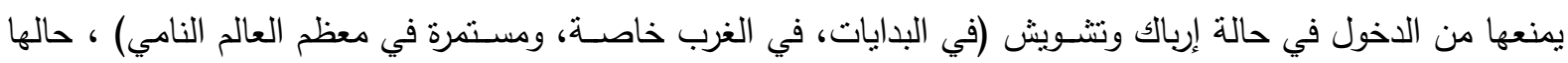

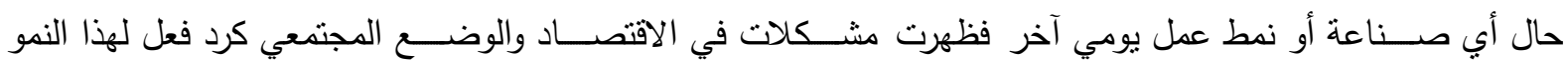
(المفاجيء والطاريء والجديد) ، لكنه في نفس الوقت أدخل أنماط هذا النمو في مفاوضات تحرير التجارة العالمية وتثجيع

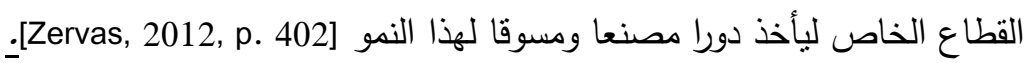

\section{3 تطور الإستدامة:}

تتعاطى الإستدامة مع الإتجاهات والحركات من بدايات تكوينها كمفهوم ، والحديث عنها والإهتمام بها ، وبدورها الكبير في

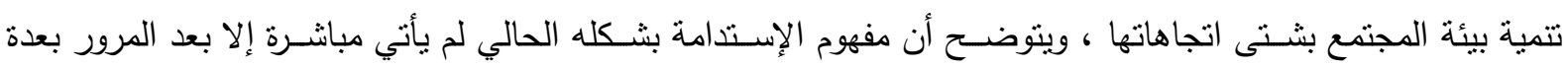

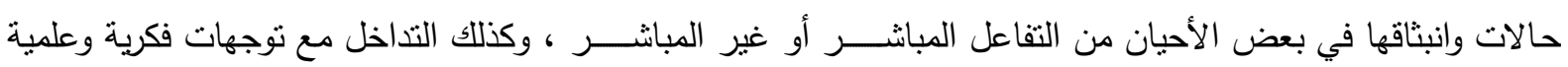

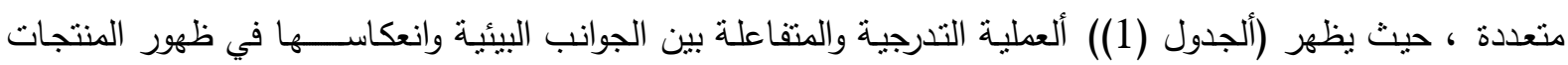

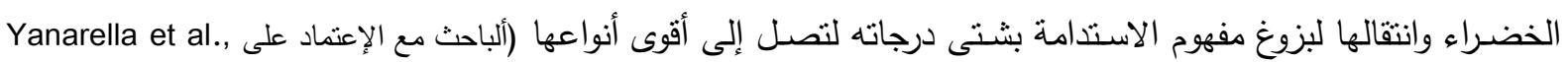

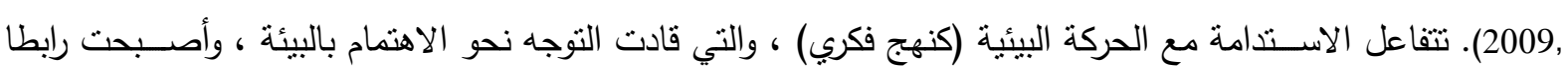

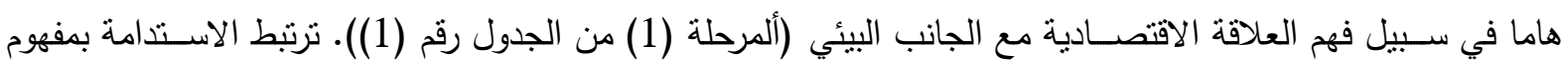

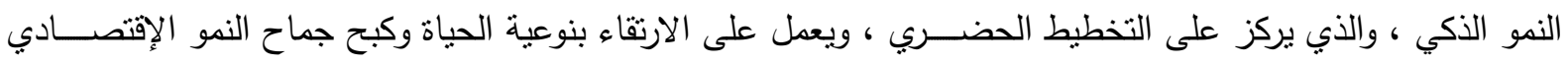

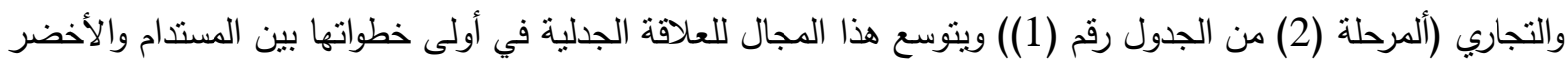

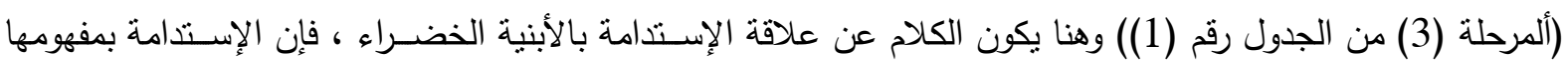
التقليدي حسب توصيات لجنة (برونتلاند) لا تمثل إلا الاستدامة بأبسط صسورها (ألمرحلة (4) من الجدول رقم (1) (1)) رغم

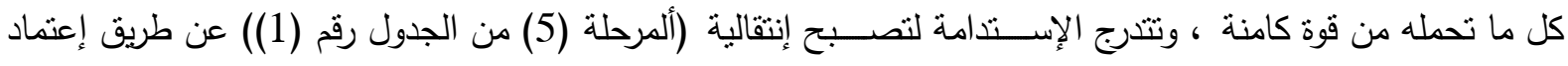

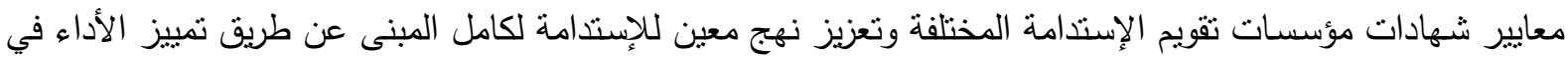

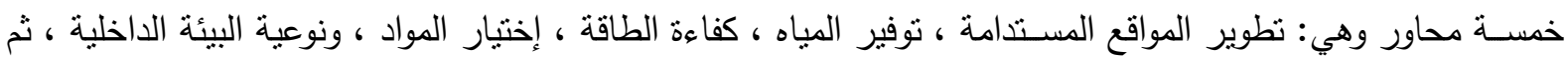
يتم الإنتقال إلى الاستدامة القوية (ألمرحلة (6) من الجدول رقم (1)) التي تتوصل إلى أن النمو (ألزيادة الكمية) غير مساو

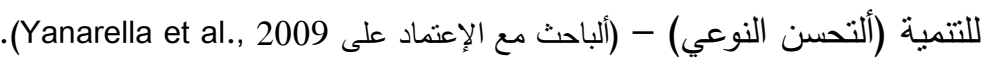

تبلغ الاستدامة ذروة تطبيقها عندما تتدرج ضمن أسس تطبيقية وعمل مؤسساتي يرعاها ، ويجعل وجودها رسميا عن طريق إطار مهني واضح يعمل على تقويم الاستدامة وإيجاد الدور الجوهري للمؤسسات الحكومية ، او تلك المهتمة والمتخصصة 
لاعم الاستدامة ، ما ييرز الحالة الوجودية التطبيقية للاسـتدامة بأقوى صـورها (ألمرحلة (7) من الجدول رقم (1)) (ألباحث

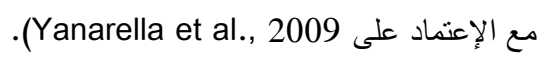
ما تقدم يدل بوضوح على الإرتباك والتشويش بين مصطلحين (ألاخضر ) و(الإستدامة) وهما يستخدمان غالبا بشكل منبادل

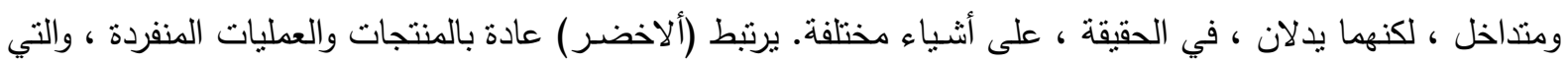
تهدف إلى ما يمكن تسميته بالحصول على نتائج إيجابية عن طريق الفرص ألني يمكن القول أنها متوافرة في بلدان متقدمة

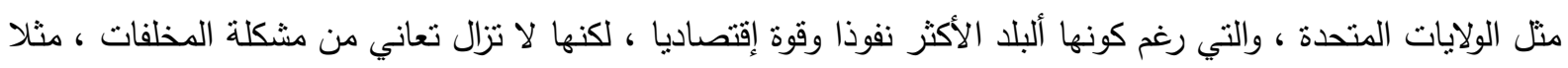

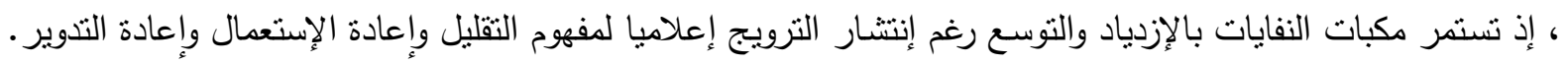
هنا تعد الممارسات الخضـراء (Green Practices) ممارسـات أمنة (من الناحية الإيديولوجية) ولا تخل بشكل (جوهري)

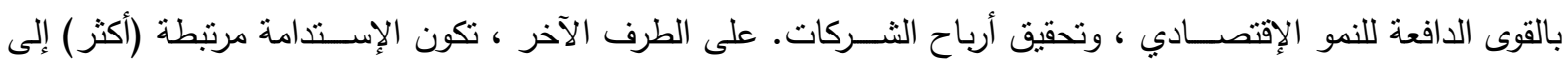

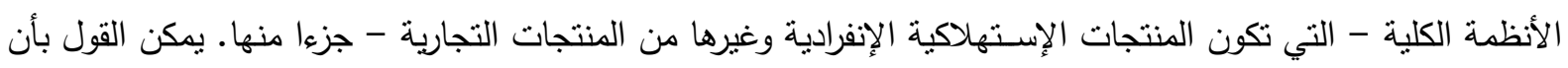

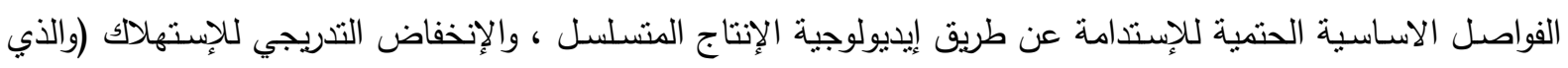

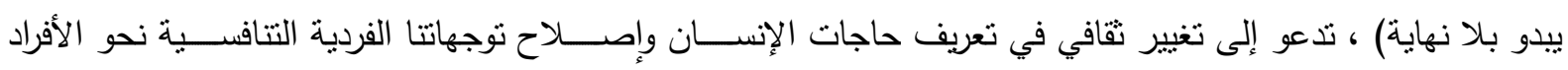

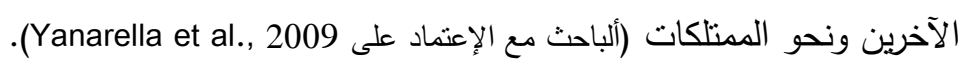

يخرج البحث بتكوين إطار تصــنيفي ، يكون بمجموعه الإطار النظري المسـتتنج والموضـــح بألجدول (2) والذي يهتم

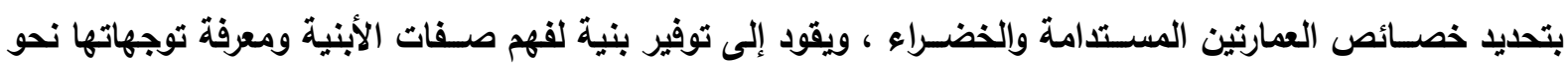
أنماط الأبنية المستدامة أم الخضراء ، أم أنها ستعد عمارة ذات خصائص وصفات مركبة ضمن تصنيف آخر يعد أكثر 
ألجدول (1) - مراحل تطور الاستدامة - ألمصدر: ألباحث مع الإعتماد على (Yanarella et al., 2009)

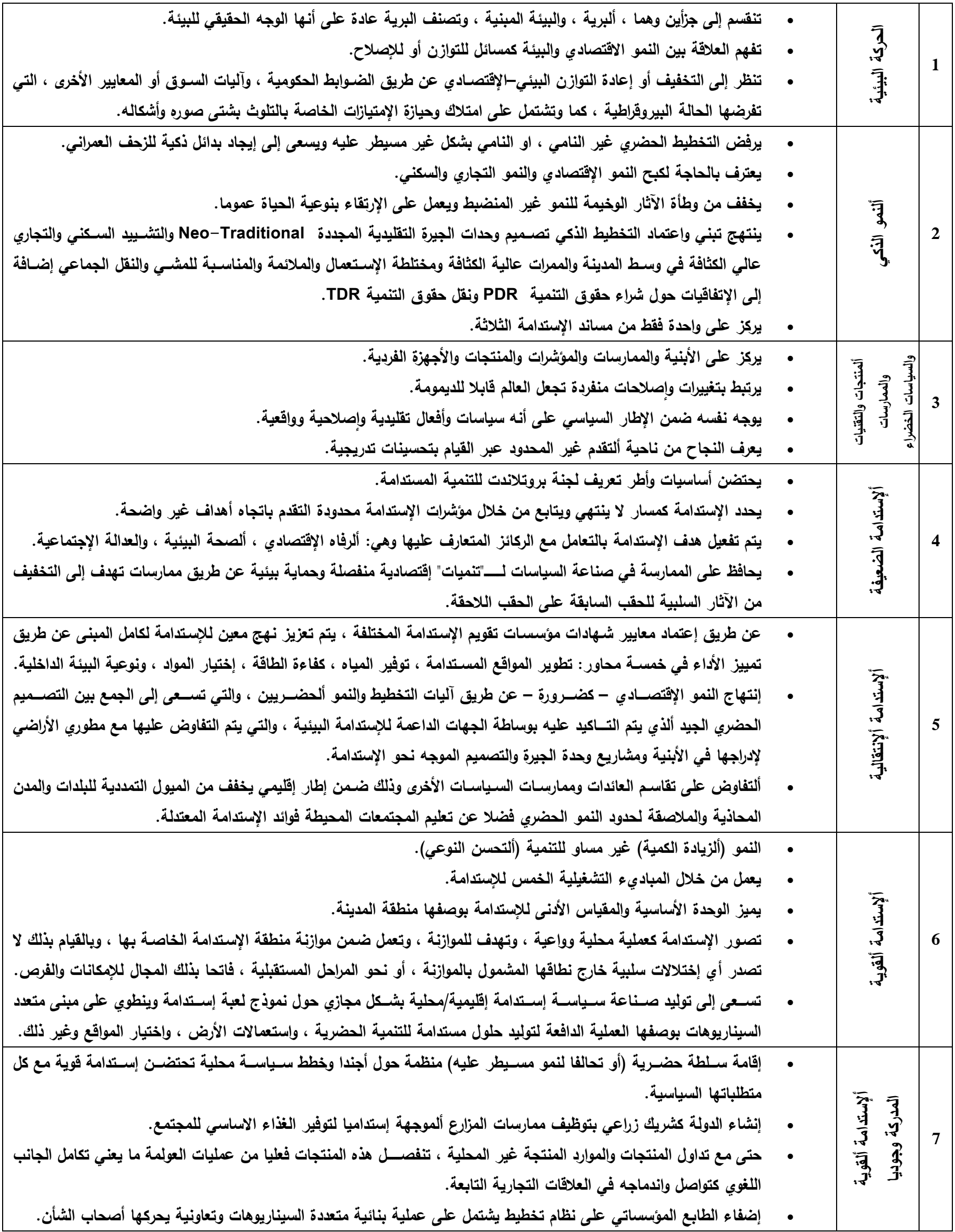


ألجدول (2) يبين مؤثرات الإطار النظري العام المستخلص من قبل البحث ، كأساس لمعرفة الفروقات بين العمارتين المستدامة والخضراء وكأساس للتحقى من المشاريع - ألباحث

\begin{tabular}{|c|c|c|}
\hline 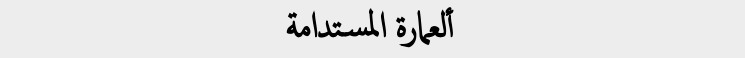 & 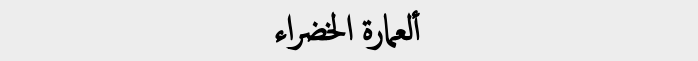 & \\
\hline 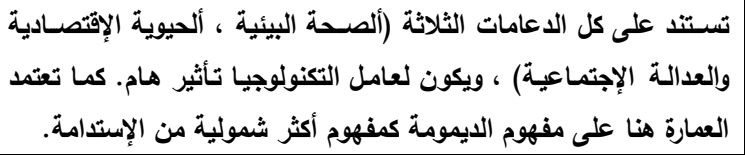 & 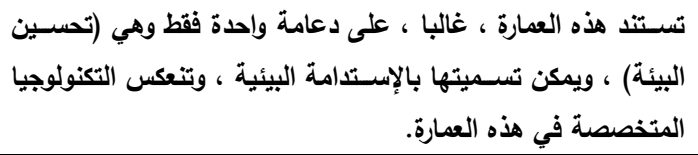 & ألعلاقة بالنسبة لاعائم \\
\hline 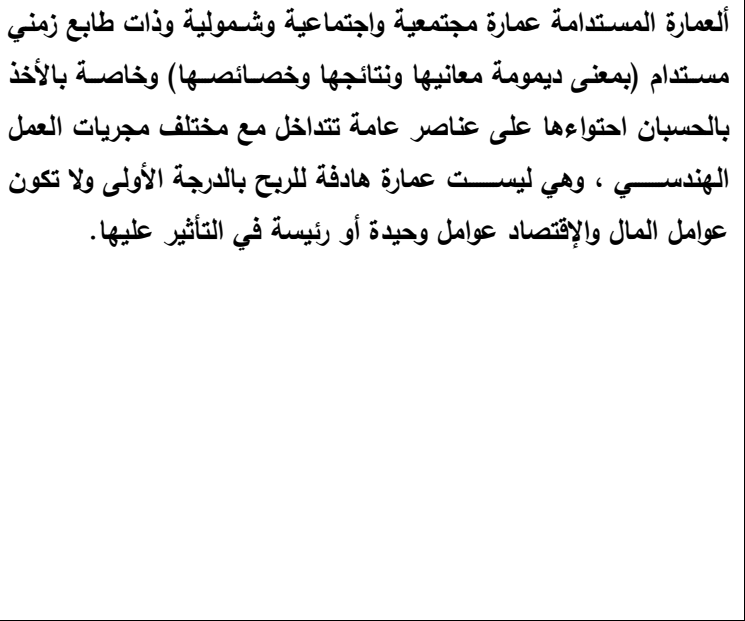 & 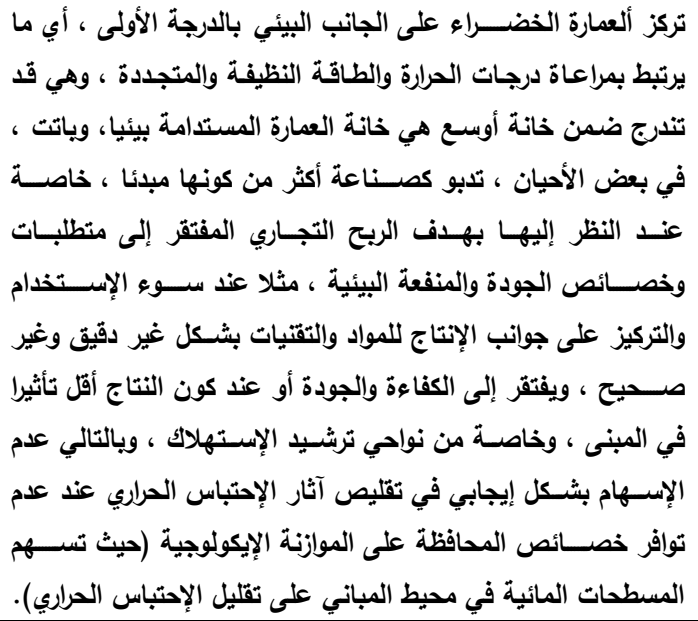 & ألجاتب العام \\
\hline 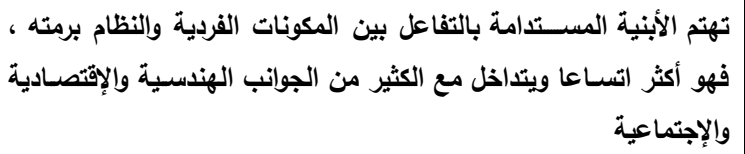 & 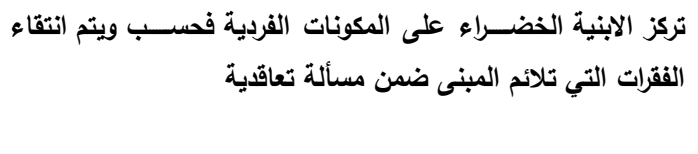 & على المكونات \\
\hline 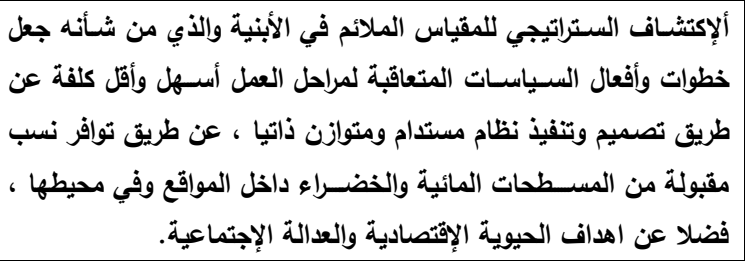 & 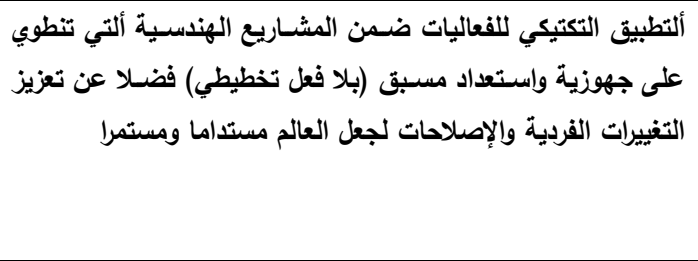 & |ألستراتيجية \\
\hline تظهر المباني المستدامة ضمن إطار إبتكاري ، كثير الروئى ، ثوري بشكل & تظهر هذه الابنية ضـمن مناخ وواقع تقليدي ، واقعي ، إصــلاحي ، & 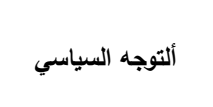 \\
\hline 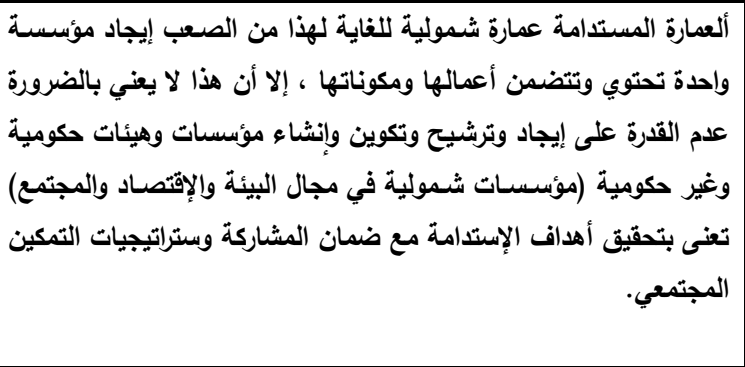 & ألألعمارة الخضـراء أكثر وضـوحا وسـهولة وتنظيما ، من حيث إلمكانية & ألجوانب الإجرائية \\
\hline 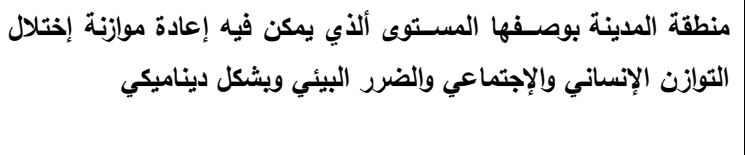 & 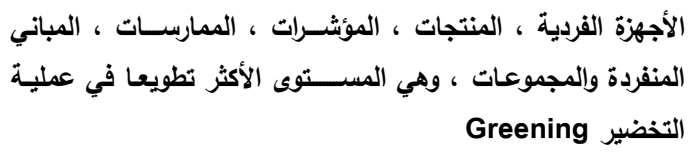 & ألمقياس \\
\hline ألتخيل الطوياوي أو ألعمل السياسي السلطوي من القمة إلى الأسفل. & 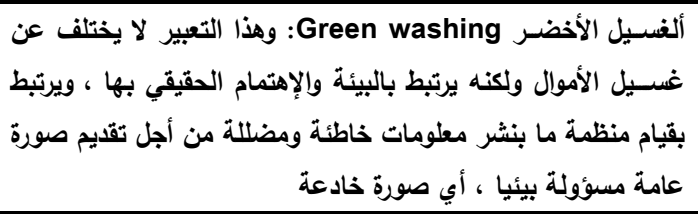 & ألمخاطر والتجاوزات \\
\hline حصة أرض عادلة خصمة القدم الإيكولوجية (ضمن البيئة الخضراء) لتصل إلى & تقام غير محدود للتحسينات التدريجية & تعريف مفهوم النجاح \\
\hline
\end{tabular}


يقوم البحث باجراء اســتعراض لمثالين عن ابنية تعاملت مع الموضــوع البيئي بعمق ضــمن نهج تطبيقي نظامي مبني

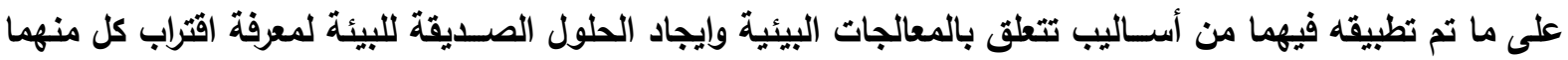
من تبني وتطبيق الفقرات المدرجة في مؤثــــرات الإطار النظري ، حيث تم تمات انتخاب مثالين (كلاهما يخدم وظيفة علمية

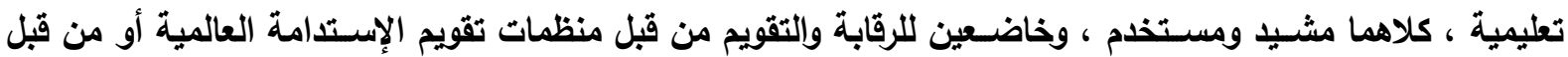
هيئات رقابية بيئية) ، وهذان المبنيان هما:

\section{أولا: مبنى أكاديمية العلوم في كاليفورنيا - سلن فرانسيكو/كاليفورنيا ، 2000-2008}

\section{Renzo Piano Building Workshop تصميم}

\section{Stantec Architecture (San Francisco), architects بالمشاركة مع}

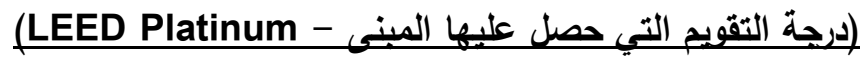

يمنل المشروع تجسيدا لتصميم مؤسسة علمية وثقافية كبيرة في مدينة سان فرانسيسكو الأميركية ، والتي تعد مدينة تميزت بكونها تدعو بشكل جماعي قوي ومتميز للبيئة. تم تأسيس أكاديمية كاليفورنيا للعلوم في سان فرانسيسكو في في العام فئه (1853)

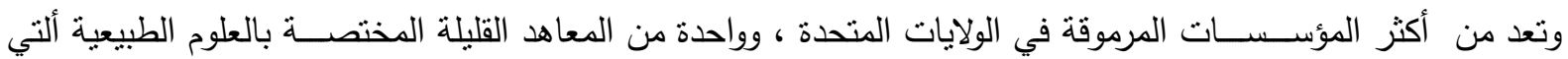
تحدث فيها التجربة المجتمعية العامة والبحث العلمي في نفس المكان. بعد التدمير واســـع النطاق الذي حصــل في في أبنية

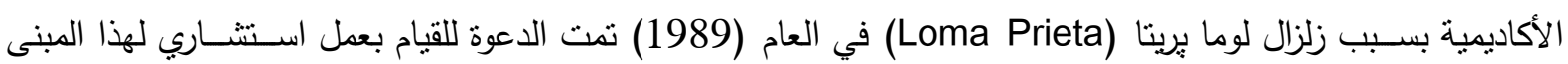
الجديد. توجد الأكاديمية الحالية في موقع (Golden Gate Park) ضمن موقع المشروع القديم والذي كان مؤلفا من (11) مبنى) بنيت بين الأعوام (1916) و (1976) وتم تجميعها حول فناء وسـطي مركزي ، ومنها ثلاث ابنية تم الحفاظ عليها

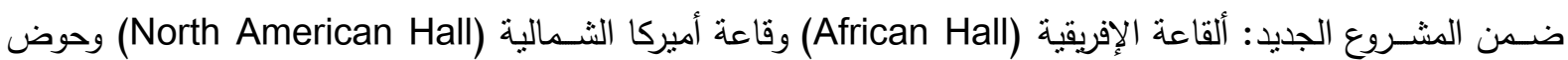
شتاينهارت للأحياء المائية (Steinhart Aquarium) واحتفظ المبنى الجديد بنفس الموقع والتوجيه الذي حظيث به الأبنية القديمة ؛ فكل الوظائف تم توقيعها حول فناء وســــي مركزي يكون بمثابة بهو للمدخل ومركز محوري يؤدي للمجموعات (Collections) تتنتمل الأكاديمية على متحف التاريخ الطبيعي ، وحوض الأحياء المائية (Aquarium) والقبة السماوية (Planetarium) ، وتتعكس الهيئات الثـكلية المتباينة لهذه العناصـر المختلفة في خط السطحح الخاص بالمبنى والذي يتبع شـكل مكوناته ،

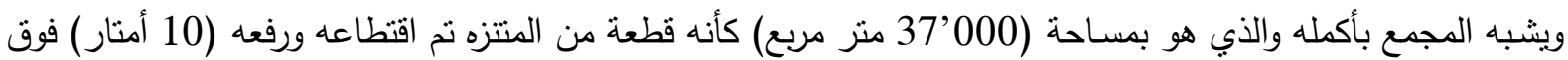
الأرض. يغطى (ألسطح المفعم بالحياة) بـــ(1’700'000) من النباتات المحلية الأصلية والتي زرعت في حاويات مصنوعة من أنسجة جوز الهند المخصبة بشكل خاص ، والقابلة للتحلل بيولوجيا. يكون السطح مسطحا ومستقيما في محيطه ، ثم يتخذ

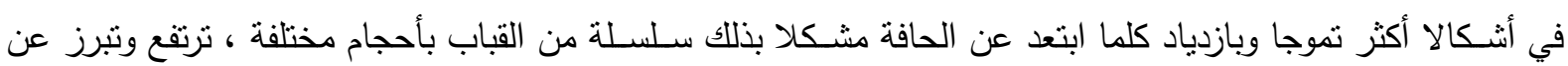
مسـتوي السطحح. تغطي القبتان الرئيسـتان منطقتي القبة السـماوية ومسـاحة معرض الغابات. تتميز القباب بوجود نمط من

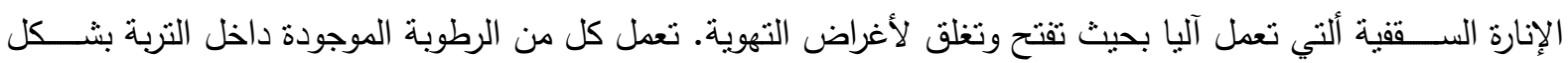

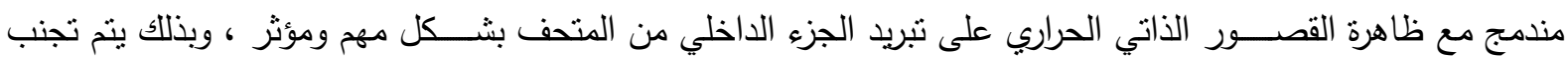
الحاجة إلى تكييف الهواء آليا في المناطق العامة والمكاتب البحثية في الطابق الأرضي ، على طونى طول الواجهة. تم وضع وتثيت الخلايا الضوئية (PV Cells) بين اللوحين الزجاجيين الذين يشكلان السقيفة الثفافة حول محيط السطح

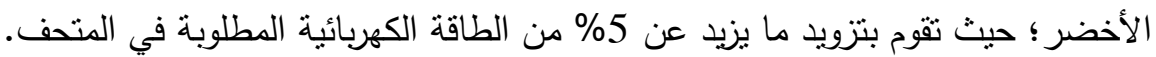




\section{Number 12 Volume 24 December 2018 Journal of Engineering}

أصبحت القضايا التصميمية الآتية: إختبار المواد ، إعادة التدوير ، نوقيع الفضـاءات نسبة إلى الإنارة الطبيعية ، ألتهوية

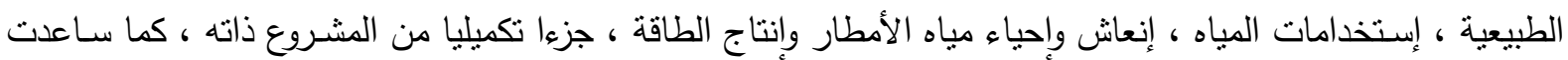

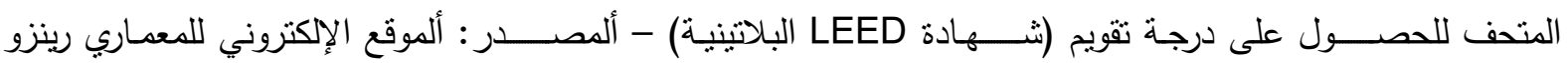

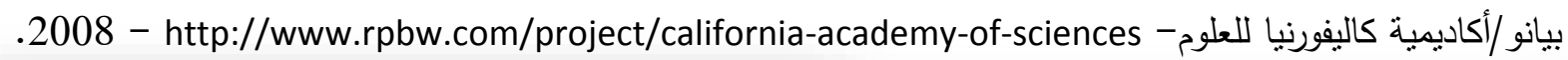
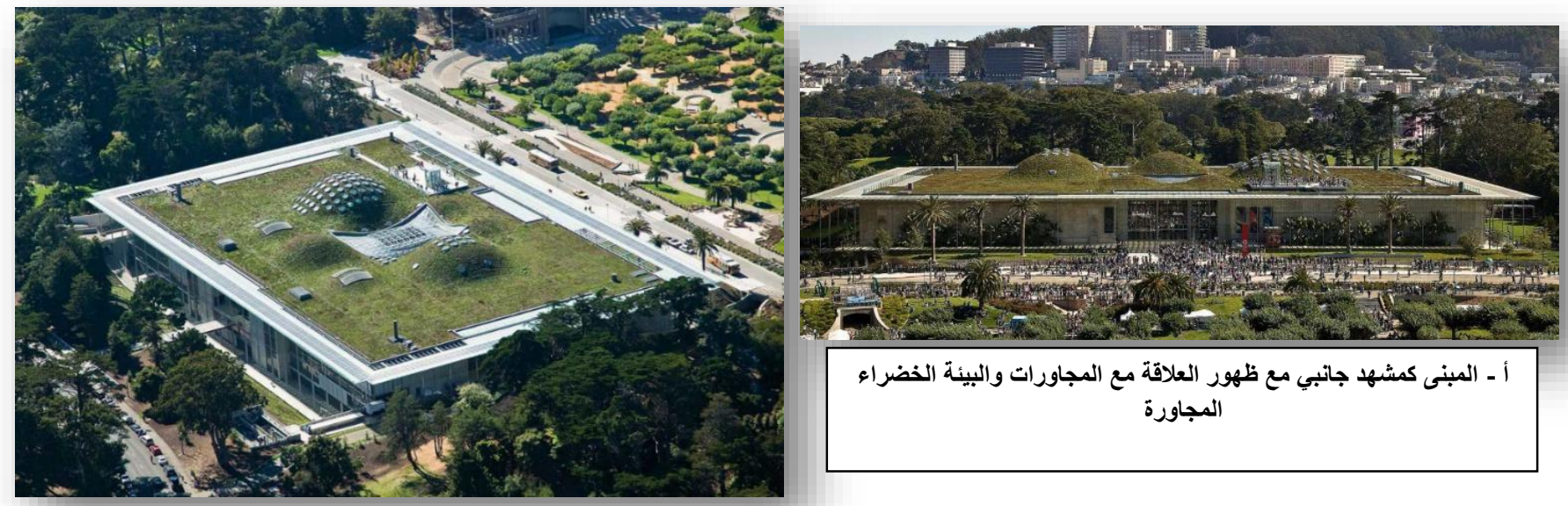

أ ـ المبنى كمشه جانبي مع ظهور العلاقة مع المجاورات والبيئة الخضراء

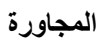

ب - صورة جوية تظهر علاقة المبنى وتفاعله مع المجاورات وانحناء السقف الاخضر بحيث يكون جزءا من المحيط الأخضر

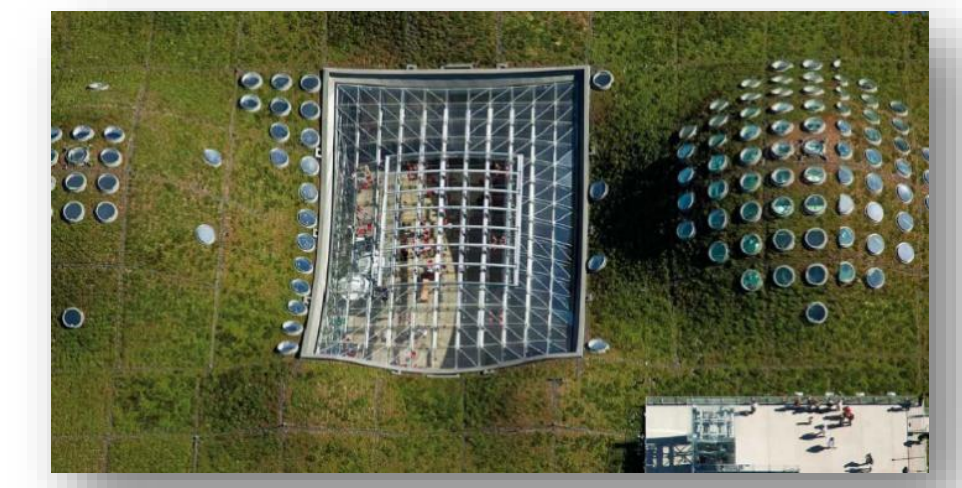

دـ ـ السطوح المتموج مع الفتحات التي تتحكم بدرجات الحرارة والرطوبة في الداخل مع الفناء

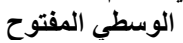
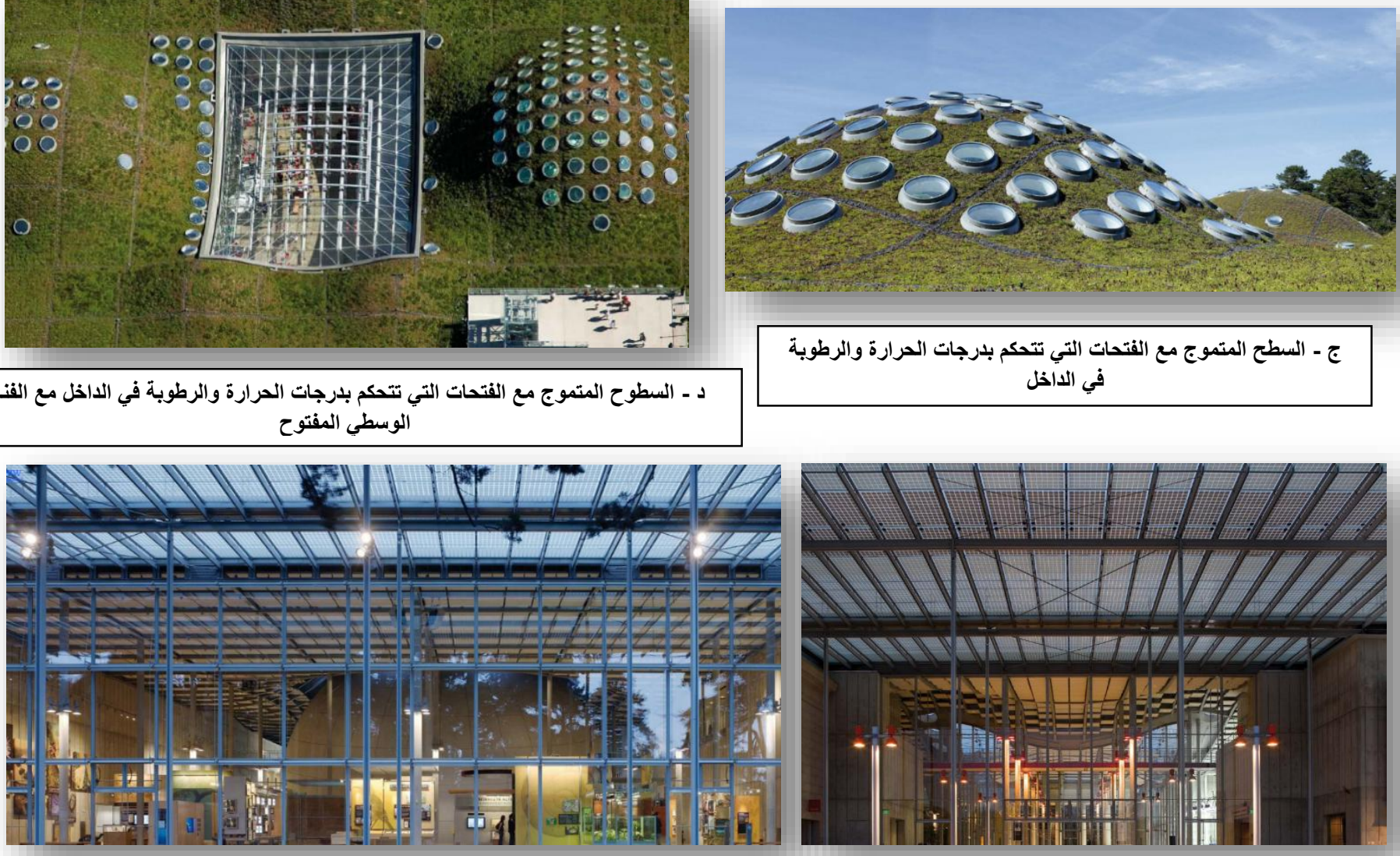

هـ ـ انسيابية الحركة الفضائية بين الداخل والخارج في المبنى وتأثير ذلك بيئيا على الفضاء الداخلي

2008 - http://www.rpbw.com/project/california-academy-of-sciences - ألثكل (1) أكاديمية كاليفورنيا للعلوم 


\begin{tabular}{|c|c|c|}
\hline ألعحارة المستدامة & ألعحارة الخضراء & \\
\hline 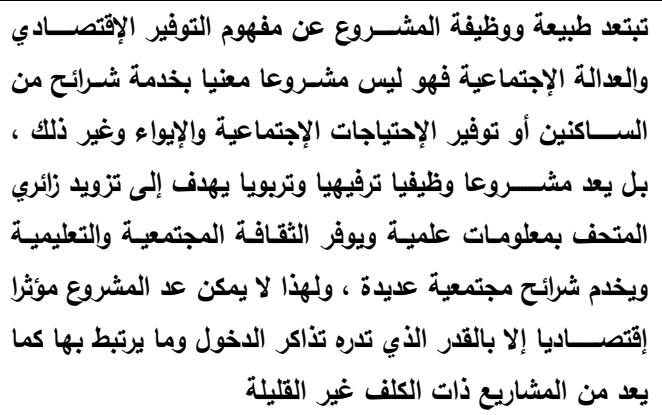 & 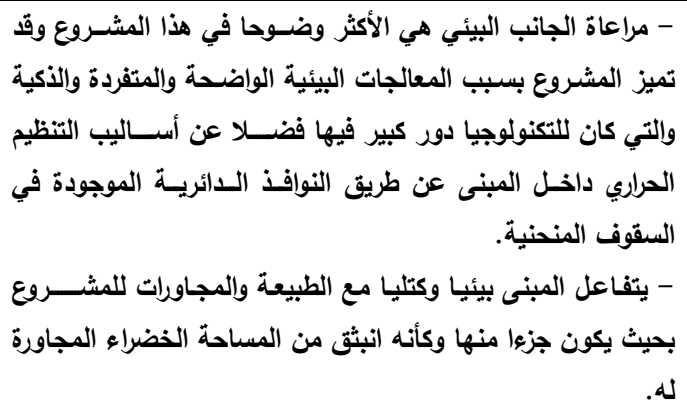 & ألعلاقة بالنسبة لاعائم \\
\hline 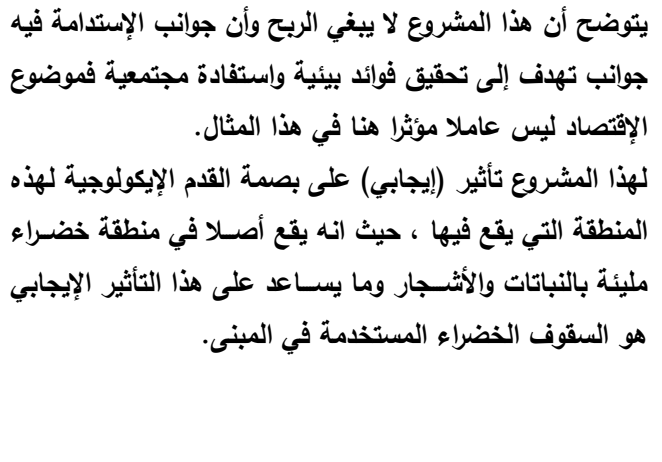 & 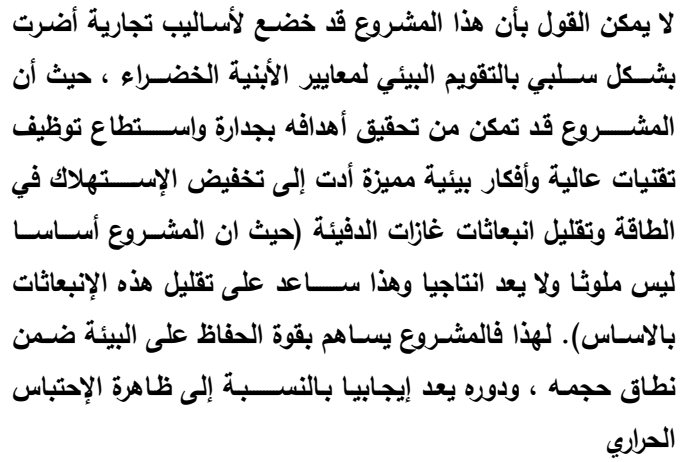 & ألجانب العام \\
\hline 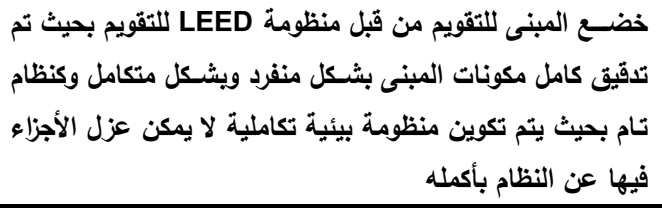 & 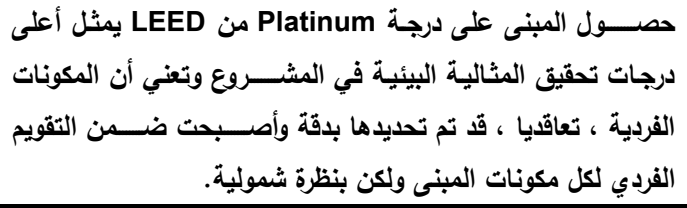 & 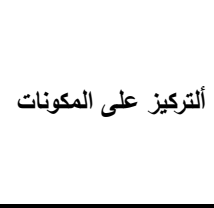 \\
\hline 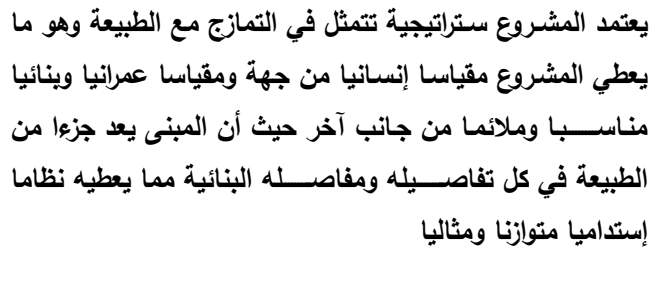 & 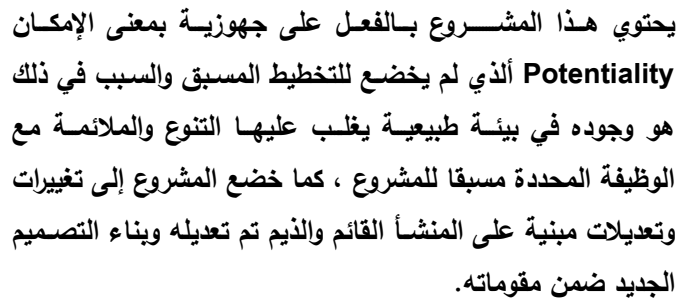 & ألتكتيكات/ألستراتيجية \\
\hline 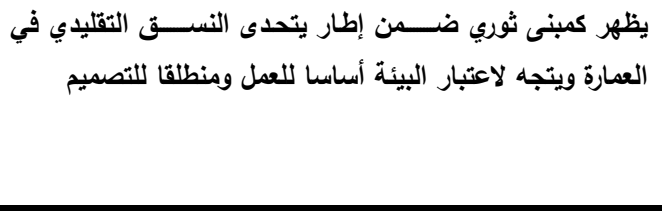 & 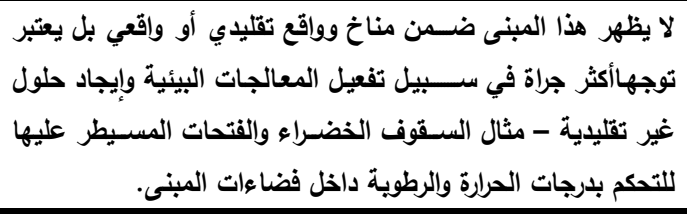 & \\
\hline لماحية الإستدامة البيئية إلتمان والإستامة البيئية في المبنى وتم التحقق من & 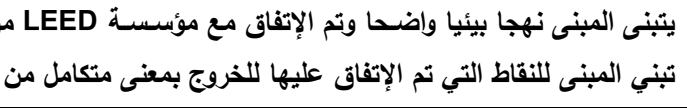 & ألجوانب الإجرائية \\
\hline 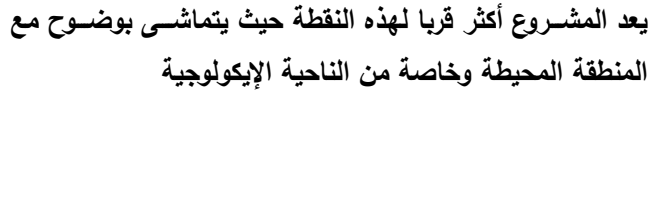 & 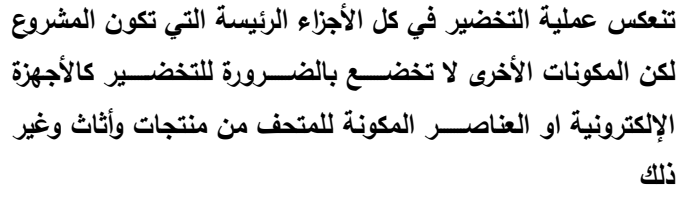 & \\
\hline \multicolumn{2}{|c|}{ 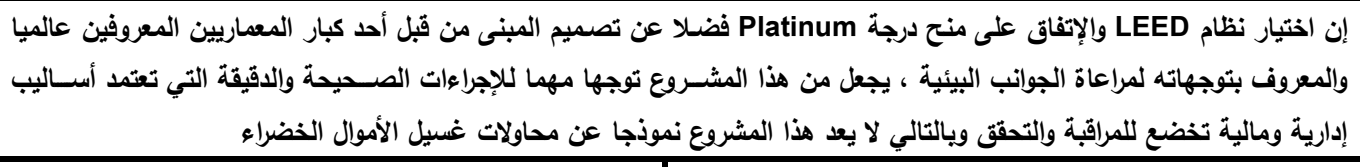 } & ألمخاطر والتجاوزات \\
\hline 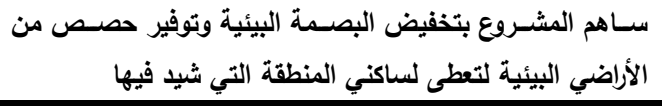 & تمكن من الإستفادة من وجود ابنية وهياكل إنشائية قليمة & تعريف مفهوم النجاح \\
\hline
\end{tabular}


يتوضح ان مبنى أكاديمية العلوم في كاليفورنيا ، وكما مبين في الجدول (3)) أعلاه ، يعد مزيجا بين كونه مبنى أخضرا ومبنى مستـاما ، لكن مؤثثرات الإطار النظري توضـح عن طريق المقارنة بأنه يميل أكثر ولو بثـكل قليل ، لكنه مؤثر في عدد من الفقرات ، لأن يكون مبنى مستداما بلرجة عالية .

\section{ثانيا: مدبنة مصدر (معر مصدر) - أبو ظبي/دولة الإمارات العربية المتحدة}

\section{مكتب فوستر ومشاركوه (لندن ، المملكة المتحدة) - 2010-Foster + Partners 2007:}

يعد (معهد مصـدر) ألجزء الأول من المخطط الأسـاس الأوسـع لمدينة مصـدر والذي مكن من إيجاد بؤرة تعليمية للبرنامج

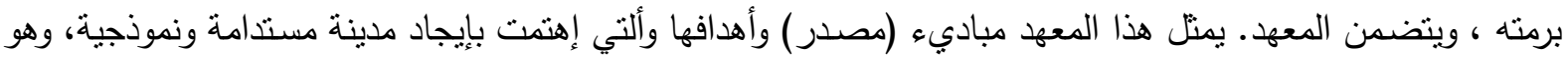
أول بناية من نوعها يتم تزويدها بكامل الطاقة عن طريق مقومات الطاقة الثمسية المتجددة.

يحتوي التصميم تتوعا من الستراتيجيات البيئية الفاعلة والمنفعلة (Passive \& Active) كوسيلة إختبار للتقتيات المستدامة

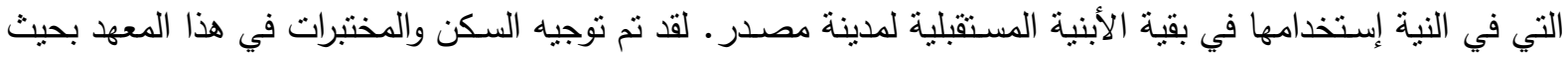
أصبحت تعطي ظلا لكل من الأبنية المجاورة والملاصـقة وأيضـا لثـوارع المشــاة كما تميزت الواجهات ايضـا بكونها ذاتية النظليل (self-shading) ، وتقوم تأسيسات كهروضوئية (Photovoltaic Installations) مركبة في السطح وبمساحة تزيد عن (5000 متر مربع) بتزويد المبنى بالطاقة الكهربائية فضـلا عن تقديمها لحماية مكثفة من أثــعة الثــســ يزود

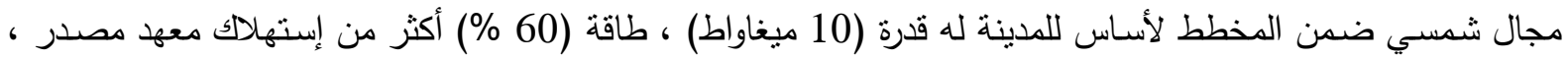
وكل ذلك يمكن أن يعود مرة أخرى إلى الثبكة الوطنية لمدينة ابو ظبي. يستخدم مجمع مدينة مصدر طاقة مياه أقل بشكل

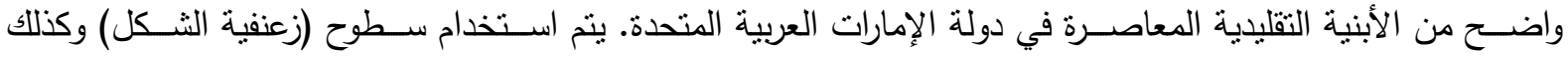
كاسـرات شـس أفقية وعمودية لتظليل الجزء الخاص بالمختبرات. يتم تشـكيل واجهات المختبرات بواسـطة وسـائد من مادة تألقابلة للنفخ والتي تمناز بقدرة عزل هائلة ، ما ييقيها باردة عند لمسها حتى تحت أثنعة شمس الصحراء القوية.

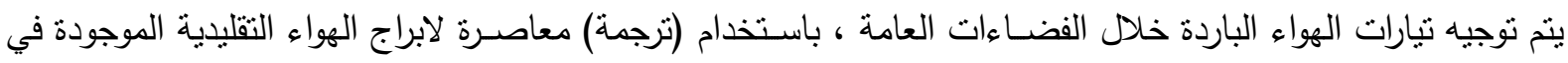

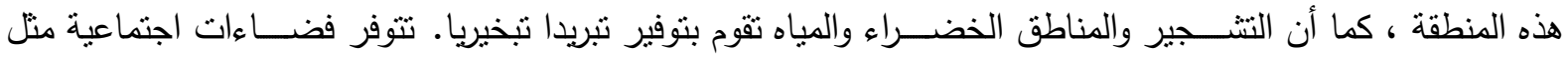
الجمنازيوم والمقصف (Canteen) والمقهى ومركز للمعرفة ومجلس ، ومساحات خضراء خارجية لتوسيع النطاق المدني.

توجد شـقق بغرفة نوم واحدة أو غرفتين أو ثلاث غرف ، وذللك في الوحدات عالية الكثافة منخفضــة الإرتفاع والتي تعطي

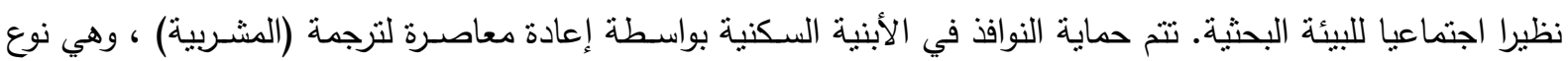
من الثــبابيك النانئة أو البارزة والتي تمتاز بكونها مشـــبكة ويتم تنفيذها بمادة GRC (وتعني ألكونكريت المدعم بالزجاج (Glass Reinforced Concrete مطورة بشكل مستدام ويتم نلوينها بواسطة الرمل المحلي من أجل إدماجها ومكاملتها

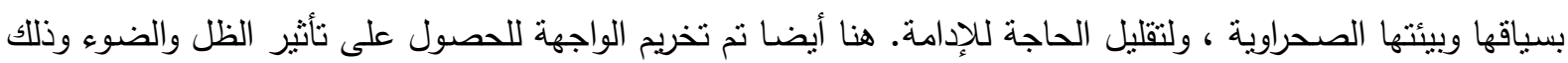

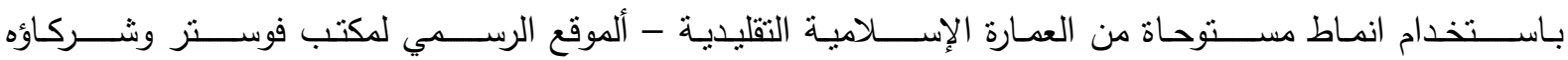
2010 - www.fosterandpartners.com/projects/masdar-institute

مادة ETFE: وهي مختصـر لـ Ethylene TetraFluoroEthylene والذي يعني بلاستك بعتمد في تكوينه على الفلور Flourine وقد تم

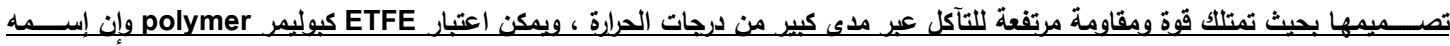

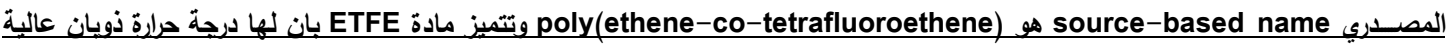
نسـبيا كما تمتاز بخصـائص مقاومة الإثــعاعات مرتفعة الطاقة والإثــعاع الكيميائي والكهريائي ، وعندما بتم حرق هذه المادة فنها تطلق حامض 
- ألمعلومات الأساسية لمعه مصدر: تمت الإحالة إلى مكتب فوستر وشركاه في العام 2007 ، وتم الانجاز في العام 2015 ويمتد المعهد على مساحة (4000 متز مربع) - منام - ألجهة المستقيدة وصاحب العمل: شركة مبادلة للنطوير والتتمية.

- مهندسو الخدمات: PHA Consult.

- ألإنــتشــاريون الإضـافيون: Clillespies, Claude Engle Lighting Design, RFD, Decarbon8, Systematica, Lerch Bates, Arup, Sandy Brown, WS Atkins, Acentech, RWDI, Mott

.MacDonald, RW Armstrong حصل المشروع على جوائز عديدة وهي: جائزة RIBA الدولية، وجوائز الخبرة الدولية البريطانية - مشروع العمارة الدولية البارزة.

- حقائق عن مصدر:

تعد مصــدر شــركة للطاقات التجارية ذات طابع تجاري ويقع مقرها في مدينة أبو ظبي عاصــــة دولة الإمارات العربية المتحدة ، وهي كمبادرة حكومية سـتراتيجية لديها تفويض في الإسـتمار في صـناعة الطاقات المتجددة وتطويرها وإنشـاءها في أبو ظبي وفي مختلف أنحاء العالم ، وتتكون شــركة مصــدر من أربع وحدات عمل وهي (مصــدر لرؤوس الأموال)

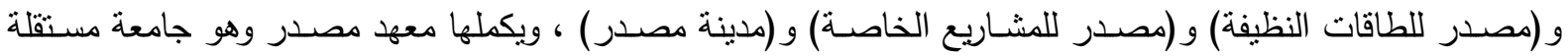
للاراسـات العليا وتعنى بالبحوث. مصدر هي شركة فرعية مملوكة بالكامل وتابعة لثـركة مبادلة للنطوير والتي هي بدورها هيئة مملوكة لحكومة أبو ظبي، وتتضوي مصدر تحديدا تحت مظلة قسم الطاقة في مبادلة.
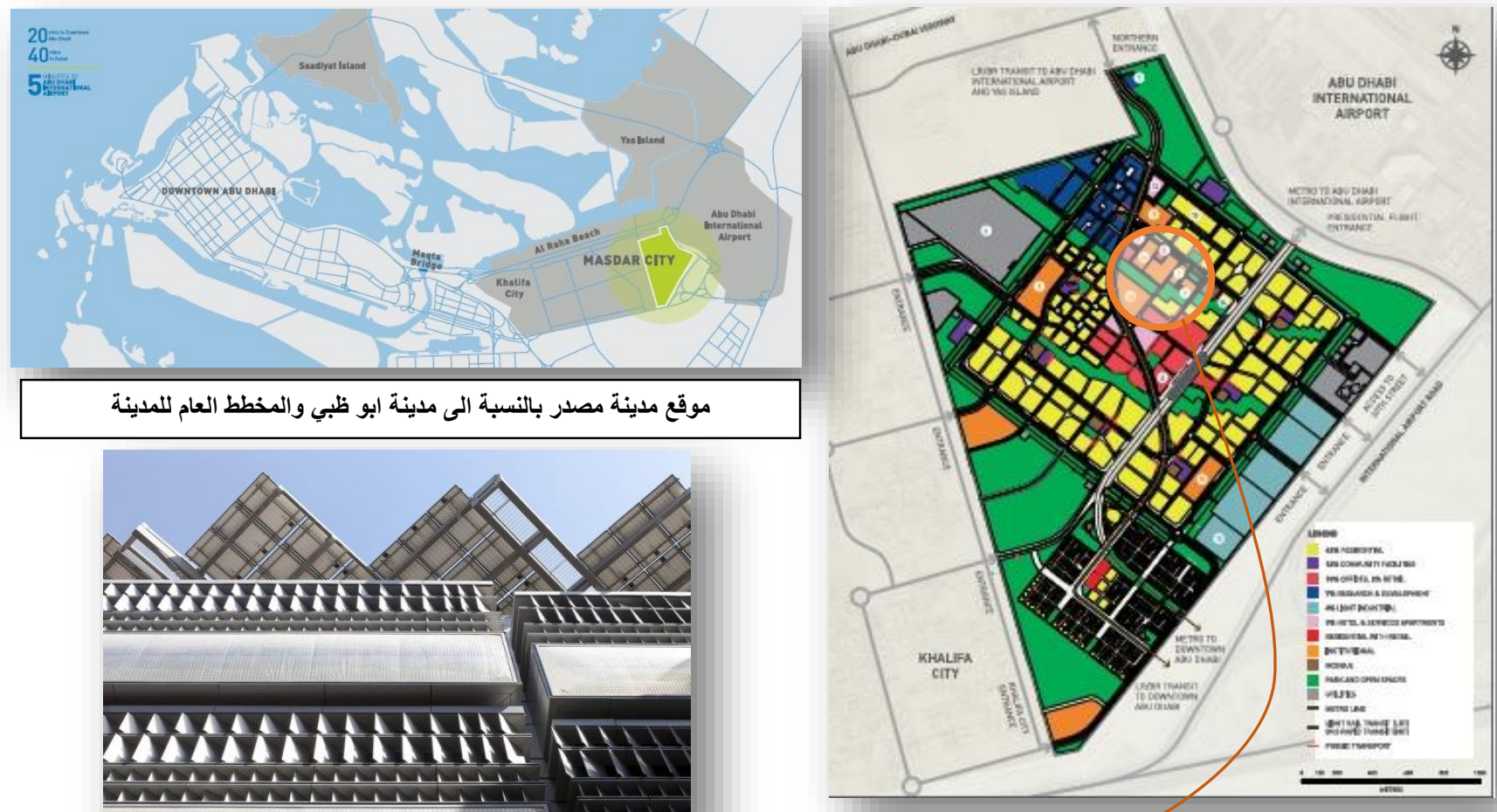

موقع معهد مصدر ضمن مدينة مصدر

الخلايا الشمسية في مبنى معهد مصدر

ألثكل (2) يوضح موقع مديمة مصدر وموقع المعه ضمنها ومعالجة السقوف بالخلايا الثمسية

www.fosterandpartners.com/projects/masdar-institute 


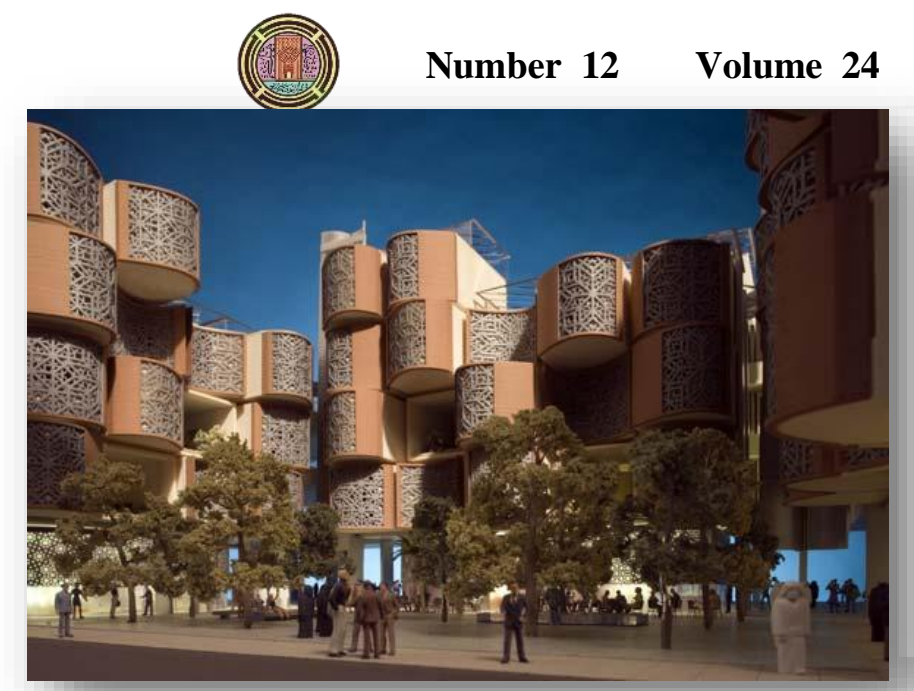

December 2018 Journal of Engineering
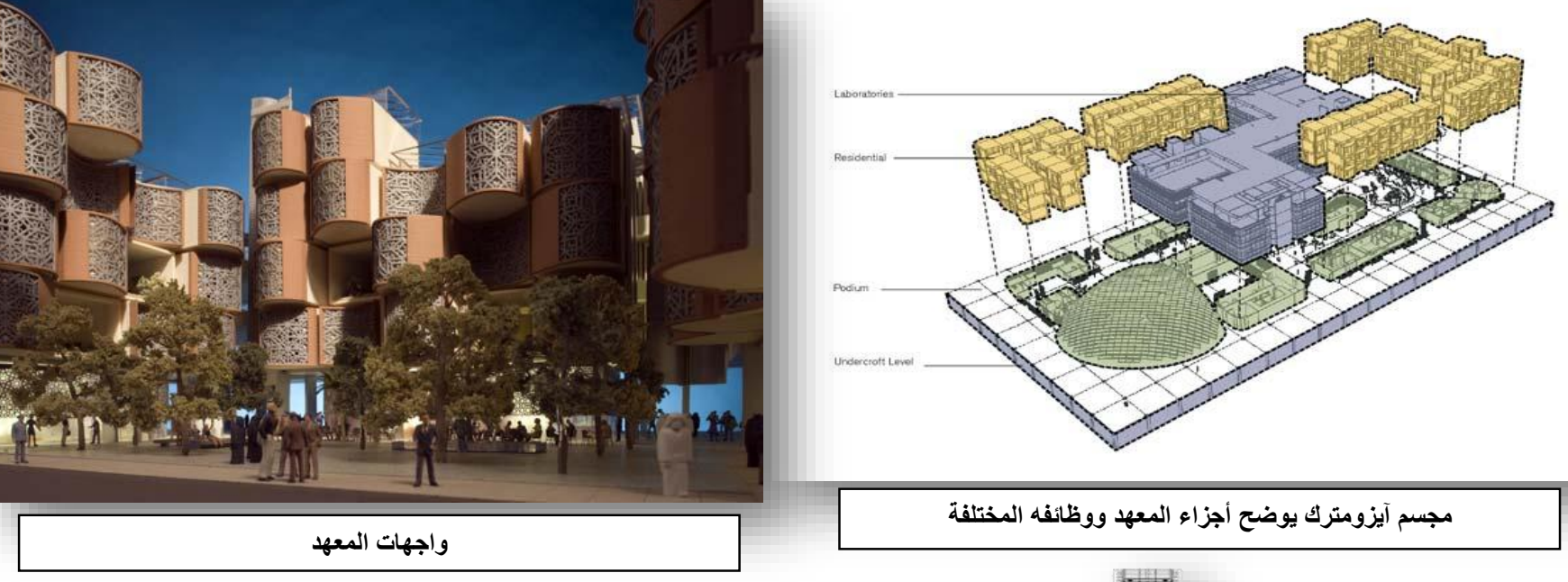

مجسم آيزومترك يوضح أجزاء المعهل ووظائفه المختلفة
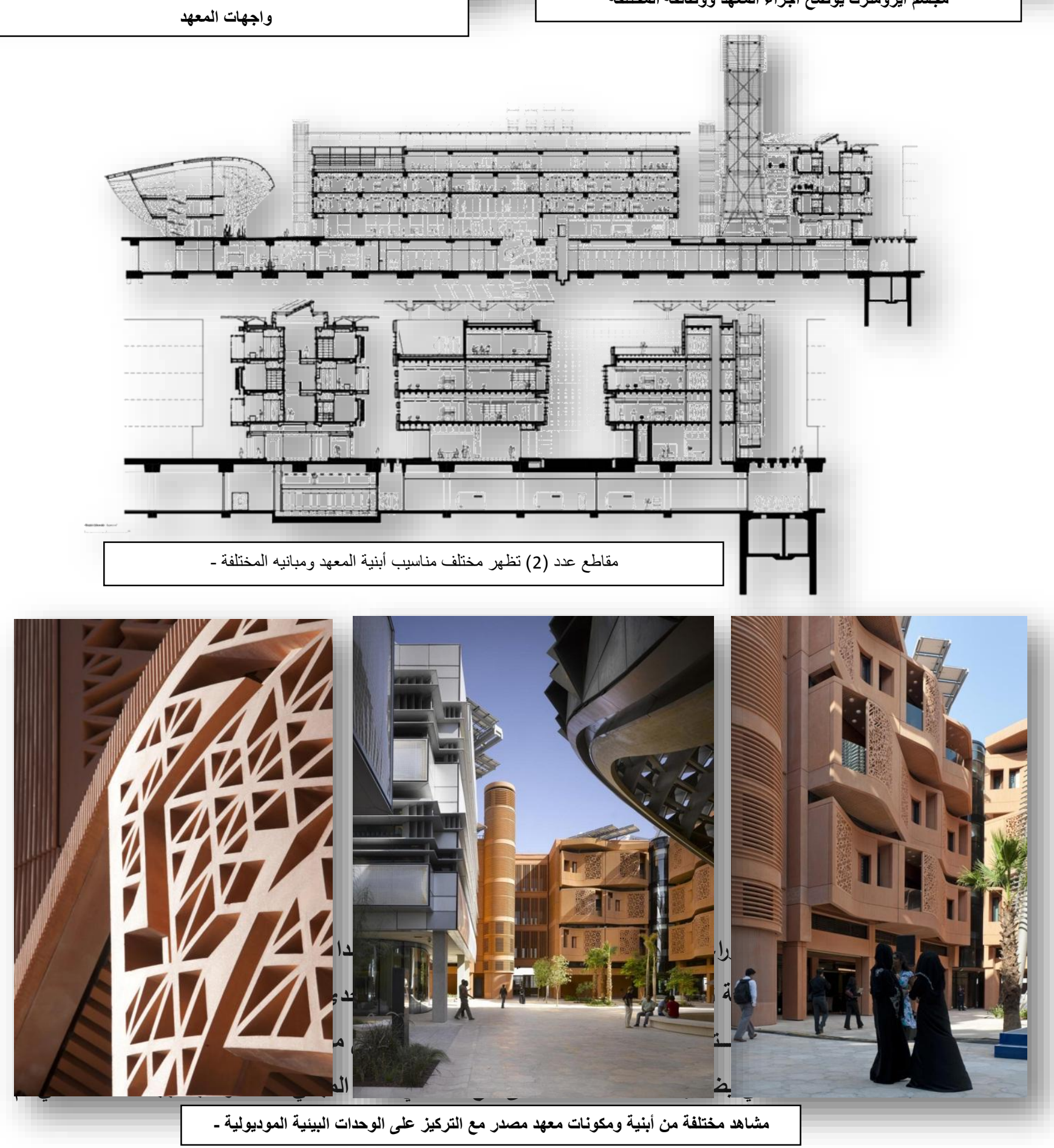

ألثكل (3) يوضح مقاطع وصور حول (معهد مصدر) في مدينة مصدر - أبو ظبي/دولة الإمارات العربية المتحدة 
ألجدول (4) يوضح تطبيق الاطار النظري على مشروع معه مدينة مصدر للعلوم والتنولوجيا في أبو ظبي (الباحث)

\begin{tabular}{|c|c|c|}
\hline ألعارة المستدامة & ألعحارة الخضراء & \\
\hline 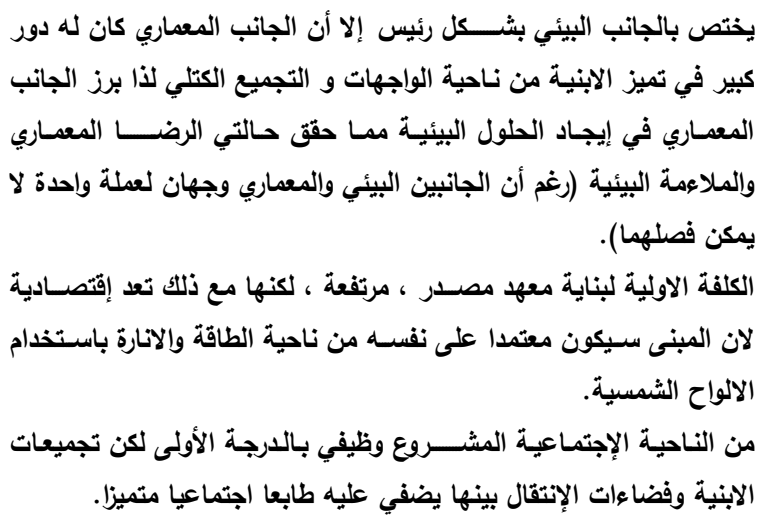 & 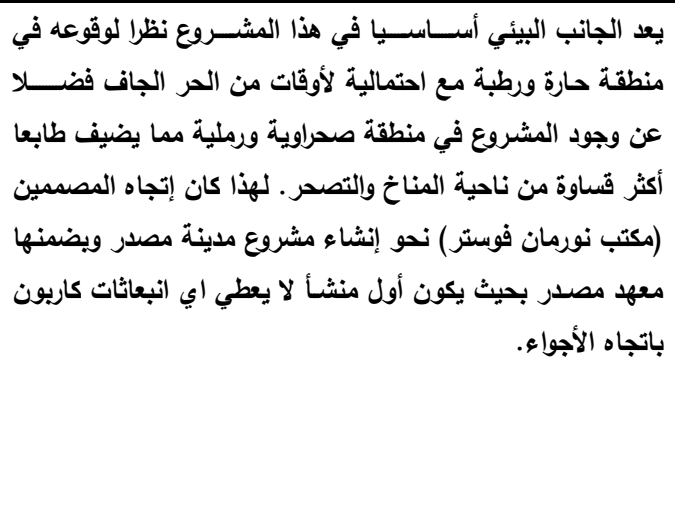 & لألعائم الإستدامة بالنسبة \\
\hline 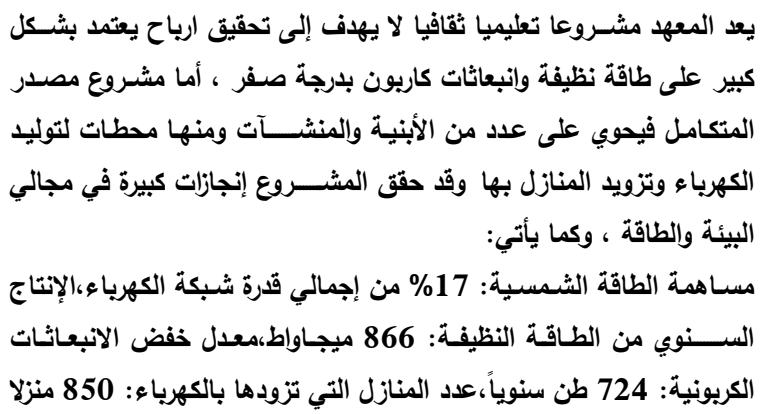 & 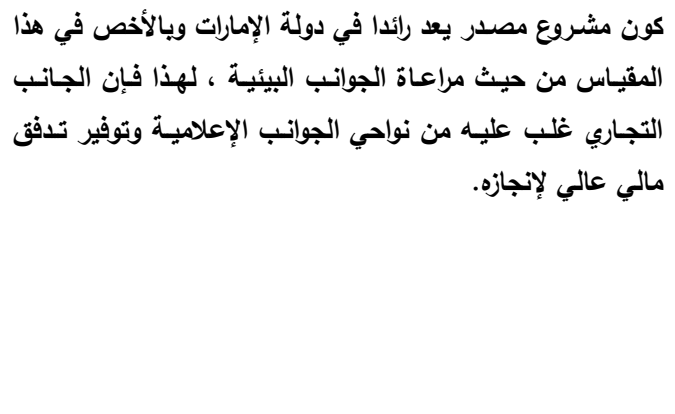 & ألجاتب العام \\
\hline 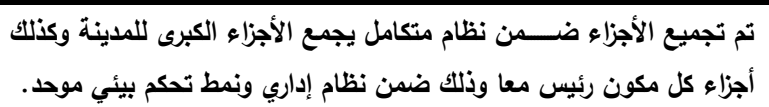 & تعد المكونات هنا على شكلين ، ألأول عد معهذ مصدر بذاته أحد المدينة والثانية كيفية التعامل مع مكونات المعهر ذاته. & ألتركيز على المكونات \\
\hline 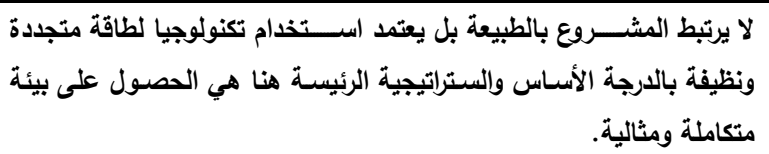 & 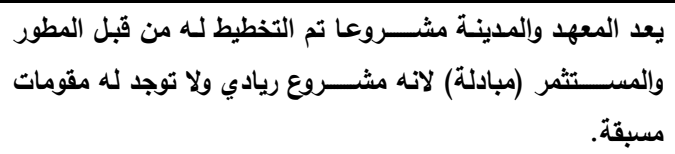 & ألتكتيكات/ألستراتيج \\
\hline تعلد الفكرة ثورية في تطبيقها وليس بوجودها فضلا عن ذلك فان نمط الابنية & 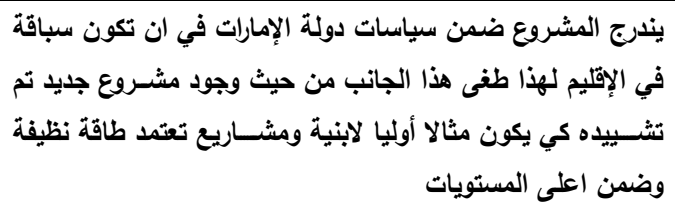 & ألتوجه السياسي \\
\hline \multicolumn{2}{|c|}{ 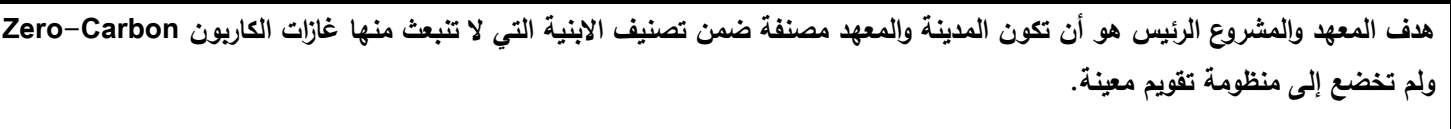 } & ألجوانب الإجرائية \\
\hline 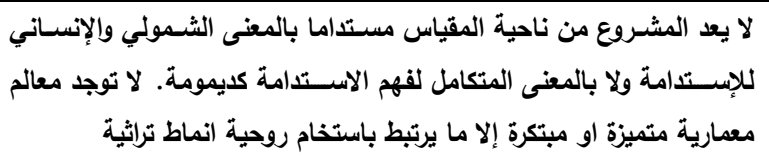 & 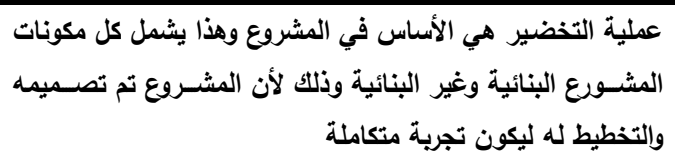 & ألمقياس \\
\hline ذلك أن المعماري الخاص بالمعها هو نورمان فوستر والذي يهتم كثيرا & يتد المشروع تجرية مهمة وتثبت نجاحها يوما بعد يوم وما ساعد ع الابنية الخضراء والعمارة المستدامة في عمله الاستثاري. & ألمخاطر والتجاوزات \\
\hline تقليل ألمشروع كجزء من مدينة مصدر يعد نواة لمساحة بنائية كبيرة تعل على الطاقة غير النظيفة & & تعريف مفهوم \\
\hline
\end{tabular}


وضعه من اجلها ، اولا ، ويسبب ما احتواه من نظم وتقنيات بيئية متميزة ، ثانيا ، وكما مبين في الجدول (4) ، أعلاه

\section{4. - ألاستنتاجات:}

1- وجود تداخل وتباين وتراكب واضح من حيث الفكر والتطبيق بين العمارة المستدامة والعمارة الخضراء فضلا عن الى المفاهيم الضمنية المرتبطة بهما والتي تكون في كثير من الاحيان متثابكة او مشتركة بينهما وتعمل على ونى

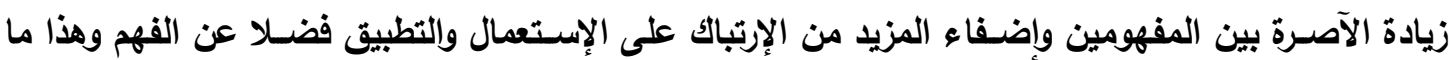

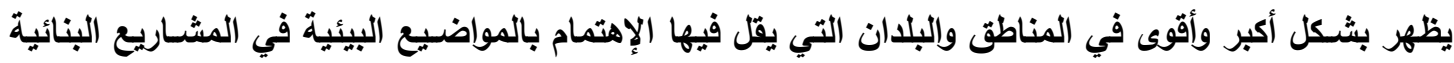
ومنها العراق الأي بدأ مؤخرا في السـير نحو تطبيق عدد من المدونات البيئية والهندسيسية والبنائية التي تعنى بالأبنية الخضـراء مع البدء بتثـييد وتصـميم مبان مسـتامة مثل مبنى البنك المركزي العراقي - من تصـيميم المعمارية زهاء حديد - وهو قيد التشييد.

2- مفهوما الإستدامة والتخضير ، بثكل عام ، مفهومان متباعدان في النشأة من النواحي الزمنية والتطبيقية ومن وهن

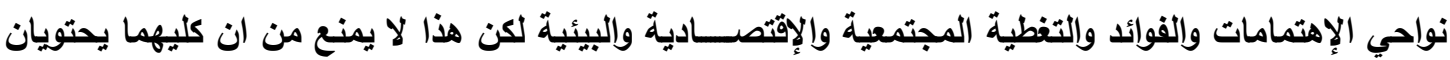

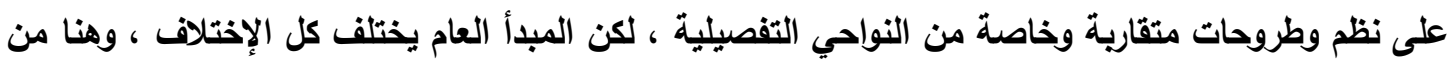
الضـروري إيجاد كيانات محلية تدعو إلى دراســة وفهم هذين القضـيتين ويثــل يامج بين الإختصــاصــات

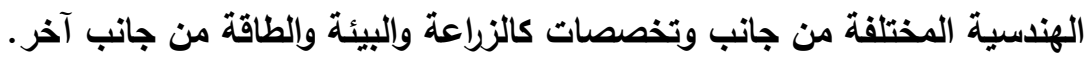
3- ألعمارة المسـتـامة عمارة مجتمعية واجتماعية وثــمولية وذات طابع زمني مسـتـام (بمعنى ديمومة معانيها ونتائجها وخصـائصــها) وخاصــة بالأخذ بالحسـبان احتواءها على عناصـر عامة تتلاخل مع مختلف مجريات

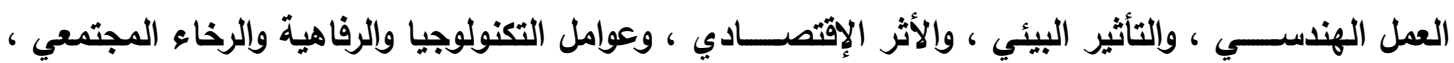

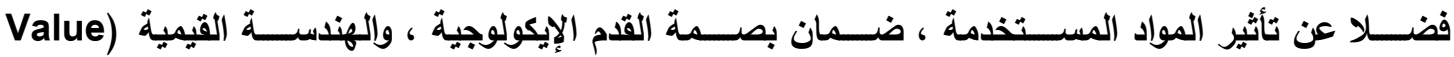

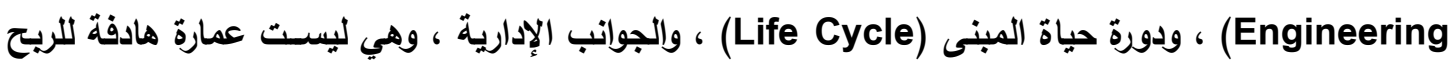

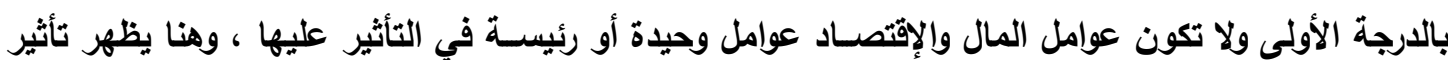
المجتمع المحلي بالنســبة للابينة في العرلق مع أهمية تطوير الكثير من الخصــائص التي تســهم في تطوير الإستدامة محليا مثل تطوير التقنيات وتمكين دور الإقتصاد وغير ذلك. 4- ألإستدامة هي تطوير تكاملي للمباني الخضراء عبر الزمن فاصبحت الإستدامة البيئية الخضراء كأحد مقومات الإستدامة المعاصرة.

5- تركز ألعمارة الخضراء على الجانب البيئي البحت بالدرجة الأولى - أي ما يرتبط بمراعاة درجات الحرارة والطاقة

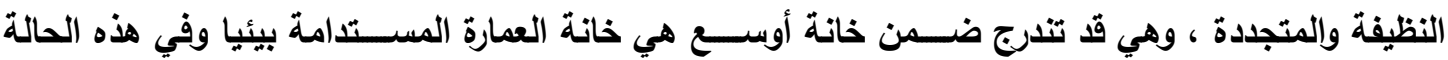
ستكون شمولية أكثر من ناحية فهم وتفسير البيئة ، فالعمارة الخضراء رغم فوائدها وثوريتها وتحريكها لعجلة التكنولوجيا الحديثة والإقتصاد وتقليل الآثار البيئية الضارة ، إلا أنها قد تحولت إلى مسألة تجارية إلى حد كبير ويمكن ان توصف بأنها باتت صناعة أكثر من كونها مبئنا ، وهذا لا يضر بها إلا في حدود سوء الإستخدام والبدء بالتركيز على جوانب الإنتاج للمواد والتقتيات بشكل غير دقيق وغير صحيح ويفتقر إلى الكفاءة والجودة أو من حيث أن النتاج سـيكون أقل تأثيرا في المبنى وخاصـة من نواحي ترشـيد الإسـتهلاك وتقليل الإنبعاثات للغازات الدفيئة ، ويالتالي عدم الإســهام بثــكل إيجابي في تقليص آثار الإحتباس الحراري. يمكن في التجرية 
المحلية التركيز في المرحلة الأولى على الجانب البيئي (أي على الجانب البيئي الأكثر تخصصـا ضمن العمارة

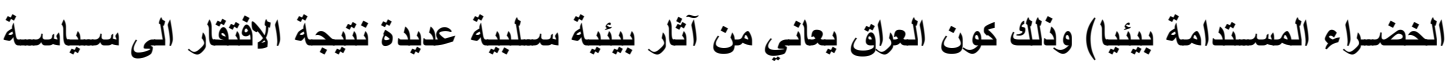
بيئية فاعلة وصارمة وشمولية.

6- ألعمارة الخضراء ، والتخضير عموما ، أكثر وضوحا وسهولية وتنظيما من حيث إمكانية الإدراج ضمن مؤسسات

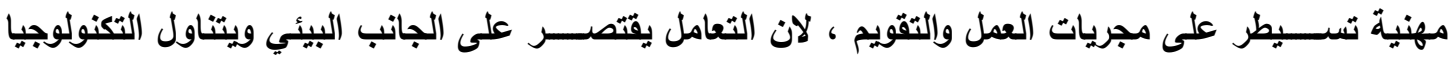

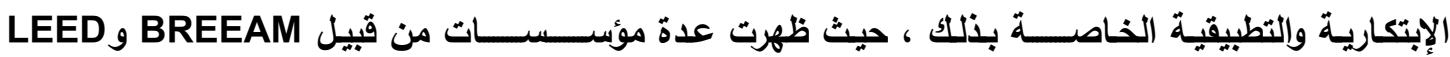
وCASBEE فضـلا عن مؤسسســات التقويم والسـيطرة في الإقليم العربي مثل نظام اللؤلؤة واسـتـامة في دولية الإمارات العربية المتحدة. 7- ألعمارة المسـتامة عمارة شـمولية للغاية لهذا من الصـعب إيجاد مؤسسـسة وإحدة تحتوي وتتضــمن أعمالها ومكوناتها ، إلا أن هذا لا يعني بالضـرورة عدم القدرة على إيجاد وترشسيح وتكوين وإنثـاء مؤسسسـات وهيئات حكومية وغير حكومية تعنى بتحقيق أهداف الإستدامة مع ضمان المشاركة وستراتيجيات التمكين المجتمعي.

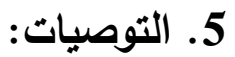

عن طريق ما طرحه البحث يتم إدراج التوصيات الآتية:

1- ضرورة فهم الفوارق بين كل من الإستدامة والتخضير وأيضا بين العمارة المستدامة والعمارة الخضراء ليتسنى تطبيق الجوانب الخاصة بكل منهما على حدة ويدون التباس.

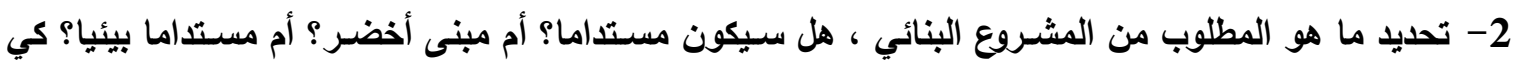

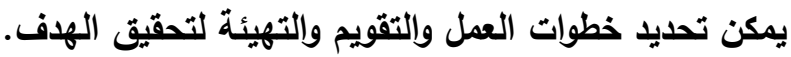
3- أهية تكوين إهتمام رسمي وشعبي وجماهيري بموضوع الاستدامة يصل الى مرحلة استحداث مؤسسات رسمية

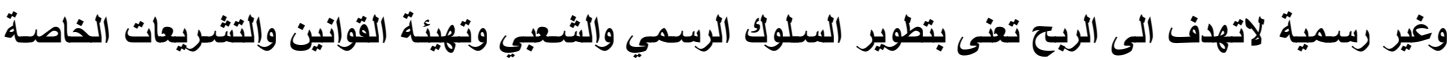
بالابنية المستدامة. 4- توفير التكنولوجيا المناسبة للابنية المستدامة والخضراء والعناية بموضوع توفير سبل التدريب اللازمة للكوادر المتخصصة في مجال الاستدامة مع اهمية توفير الخبراء في تقويم الابنية لمعرفة تحقق الاستدامة فيها وإلذين يسمون مقيمين او مخمنين (Assessors).

6. المصادر References:

Books, Essays, Researches, and Papers:

- Governor's Green Government Council (GGGC), 2015, What Is A Green Building? Fundamental Principles of Green Building and Sustainable Site Design, Building Green in Pennsylvania.

- International Labor Office (Geneva), 2013, (Report V: "Sustainable Development, Decent Works and Green Jobs"), International Labor Conference, $102^{\text {nd }}$ Session. 
- Meadows, D. H., Meadows, D. L., Randers, J. \& Behrens III, W. W., 1977, The Limits to Growth", A Report for the Club of Rome's Project on the Predicament of Mankind, A Potomac Associates Book.

- Piraget, D. C. (Editor), 1977, Intorduction: A Social Design in Sustainable Growth", in the Sustainable Society: Implications for Limited Growth, (New York: Praeger, 1977).

- Poveda, C. A. \& Lipsett, M. G., 2011, A Review of Sustainability Assessment and Sustainability/Environmental Rating Systems and Credit Weighting Tools, December 1.

- Saisana, M. \& Philippas, D., 2012, Sustainable Society Index (SSI): Taking Societies' Pulse along Social, Environmental and Economic Issues, The Joint Research Centre audit on the SSI, European Union.

- Yanarella, E., Levine, R. \& Lacaster, R., 2009, Green versus Sustainability: From Semantics to Enlightenment, Sustainability Review, Mary Ann Liebert, Inc., Vol. 2 No. 5 , October.

- Zervas, E., 2012, Green Growth versus Sustainable Development.

\section{Internet References:}

- www.fosterandpartners.com/projects/masdar-institute

- www.rpbw.com/project/california-academy-of-sciences

- dictionary.cambridge.org

- dictionary.cambridge.org/dictionary/english/greening.

- en.wikipedia.org

- https://en.wikipedia.org/wiki/Greening

- https://en.wikipedia.org/wiki/Sustainable_architecture

- www.un.org/sustainabledevelopment/news/communications-material/

- archive.epa.gov/greenbuilding/web/html/

- Sustainable Development Goals: 17 Goals to Transform Our World http://www.un.org/sustainabledevelopment/

- http://www.wbdg.org/design-objectives/sustainable 